\title{
Techno-Economic Feasibility Study of Solid Waste Recycling System for Dry Waste from Water Treatment Plants: Sultanate of Oman Case
}

\author{
Mohammed Saif Alsaidii ${ }^{*}$, Peter V. Dudin², Ilyes Jedidi ${ }^{3}$ \\ ${ }^{1}$ Department of Engineering, University of Technology and Applied Science, Suhar, Sultanate of Oman \\ ${ }^{2}$ EnCata (Engineering Catalyst), Minsk, Belarus \\ ${ }^{3}$ Department of Chemistry, University of Technology and Applied Science, Suhar, Sultanate of Oman \\ Email: *mohammed.s.alsaidi@gmail.com,pd@encata.net, ilyesjedidi.soh@cas.edu.om, ilyesjedidi@yahoo.com
}

How to cite this paper: Alsaidi, M. S., Dudin, P. V., \& Jedidi, I. (2021). Techno-Economic Feasibility Study of Solid Waste Recycling System for Dry Waste from Water Treatment Plants: Sultanate of Oman Case. Technology and Investment, 12, 16-42. https://doi.org/10.4236/ti.2021.121002

Received: October 10, 2020

Accepted: February 17, 2021

Published: February 20, 2021

Copyright (c) 2021 by author(s) and Scientific Research Publishing Inc. This work is licensed under the Creative Commons Attribution-NonCommercial International License (CC BY-NC 4.0).

http://creativecommons.org/licenses/by-nc/4.0/

\begin{abstract}
The production of human-produced wastes is increasing with the growth of the world's inhabitants. As a result, the sustainable management of huge amounts of waste is becoming an increasingly challenging task. One of these challenges is the solid waste produced by the increasing number of water treatment plants (WTPs). This paper is reviewing and proposing a recycling system which may have a technical and economical feasibility for Oman and GCC. The Proposed Recycling system for dry waste from Water Treatment Plant (WTP) in this paper is expected to be able to operate in Omani operation conditions and GCC. It has been patented as a utility model. The assumed feed for the purpose of presenting economically viable case is assumed to be around 100 tons/day. This assumption could go higher depends on the demand.
\end{abstract}

\section{Keywords}

Techno-Economic, Feasibility, Waste, Treatment, Oman, Sewage, Recycling System, UTAS-Suhar

\section{Introduction}

The quantity of worldwide wastewater has been increasing rapidly in the last decades due to the rapid population growth and, thus, increased water use for various purposes. Wastewater, if not properly treated, can cause different harms and deteriorate the ecological situation. In particular: 
- Sewage water has an unpleasant odor, which affects the city image and comfort of people living close to the sewage treatment plants.

- Tanks with sewage water from residential areas and manufacturing facilities quickly become overloaded, and more sewage treatment plants are needed. It increases public spending.

- Sewage treatment plants produce by-products of sewage treatment, which need to be utilized at landfills. It means more area and money are needed.

- Wastewater coming from industrial estates typically contains heavy metals: arsenic, lead, mercury, cadmium, chromium, copper, nickel, silver and zinc. The discharge of high amounts of heavy metals into water bodies leads to several environmental and health impacts. If wastewater is not treated properly, it may leach to ground waters. The consequence of it is the reduction in quality and quantity of food, reduced plants' growth and uptake of nutrients, physiological and metabolic processes.

- Wastewater contains antibiotics and drugs. Current wastewater treatment plants are not designed to remove micro-pollutants such as antibiotics and antibiotic-resistant bacteria and genes. Thus, these biological components might end up in the wastewater treatment plant effluent, as they are not fully removed by current treatment technologies. As a result, they may reach surface water, groundwater and potentially, drinking water. And this poses a serious threat to human health.

- Wastewater contains harmful bacteria, parasites, pathogens viruses and different organic components. As in the previous case, not all of them are eliminated at treatment plants, so there is a high risk they may get into drinking water and even food chains and affect the health of humans, animals, and plants.

In order to assess the available methods for sludge utilization and choose the most suitable one, it is necessary to consider current trends in Oman.

\section{Project Motives}

\subsection{Demand and Growth Review}

According to the published data by National Centre for Statistics and Information (NCSI) (Oman, 2019) and GCC Statistical Centre (GCC-STAT, 2019), Population in Oman (Omanis + expatriate) has been growing since 2008 and reached $4.8 \times$ $10^{6}$ in 2018 , thus, increasing by $6 \%$. This trend is likely to continue, and by 2022 Oman's population is projected to reach $6.1 \times 10^{6}$, thus, increasing by $26 \%$ since 2018 (see Figure 1).

Population growth will trigger the following complications: first of all, increased demand for water, which proves the Water statistics report. According to it, water consumption in Oman is gradually increasing and expected to rise by $52 \%$ in 2022 as compared to 2018 , i.e. from $370 \times 10^{6} \mathrm{~m}^{3}$ to $562 \times 10^{6} \mathrm{~m}^{3}$ (see Figure 2). As a result more water will need to be treated which mean solid waste from the WTP will be produced. 
Moreover, from the graphics it can be noted that water consumption is growing due to the growth of the population. However, the growth for water demand is almost 2 times higher than that of the population, i.e. $6 \%$ and $11 \%$ in 2008-2018, and $26 \%$ and $52 \%$ in 2018-2022 (see Figure 3). The increased demand for water means the increased use of freshwater for various purposes, accordingly treating waste water from different resources.

Also the published data by GCC-STAT, Countries of the Gulf region have managed to provide a steady growth of the available fresh water in recent years. The amount of freshwater was rising from 2008 till 2015, increasing by $8 \%$. However, in $2016 \%$ there was a $2 \%$ decline. The problem may become more severe due to the constant growth of the population. And in case this negative trend continues, the total amount of the available freshwater will drop by $14 \%$ (see Figure 3). In order to stop it, the government may either try to curb the growth of the population or use more efficient technologies of sludge utilization to provide a needed amount of freshwater. In any case, it will take time to reach

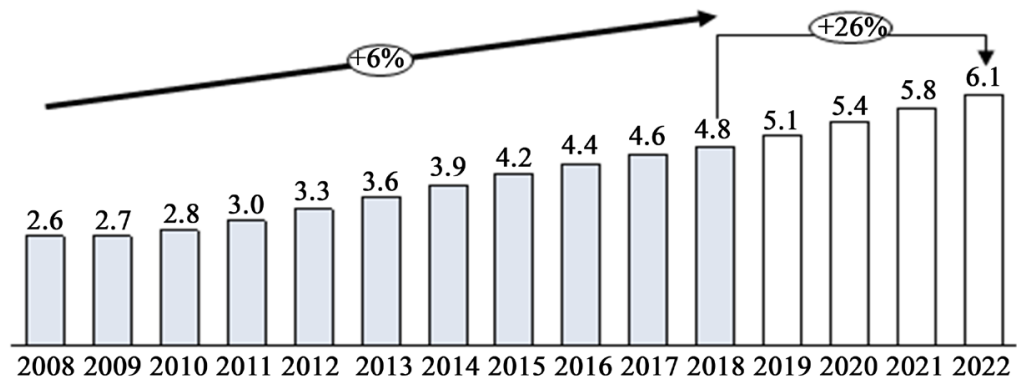

Figure 1. Oman population growth.

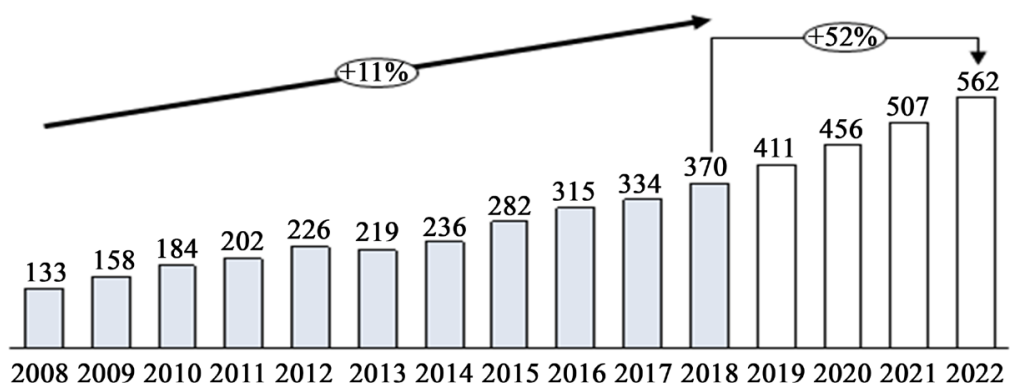

Figure 2. Oman water consumption.

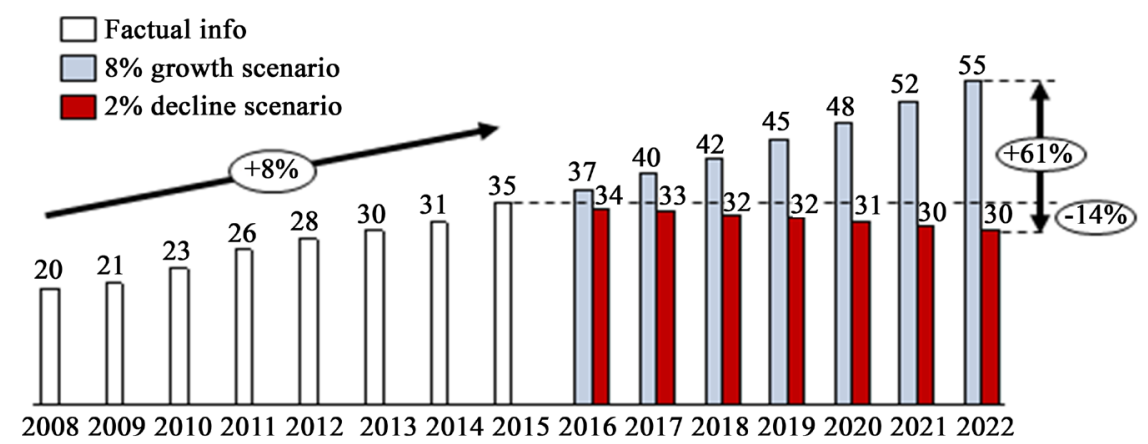

Figure 3. Comparison between growth and decline scenarios. 
the forecasted amounts of freshwater.

The published data by National Centre for Statistics and Information (NCSI), GCC Statistical Centre (GCC-STAT) and International Energy Agency (IEA) (IEA, 2019) all assumed that the growing consumption of water and the increased need for freshwater affect electricity production in Oman, which has been growing steadily from 2008 onwards and which is 3 times higher than in the rest of the world. This tendency is likely to continue, so it is expected that electricity production will reach a $54 \%$ increase in 2022 , while world electricity production may grow by just 16\% (please refer to Figure 4 and Figure 5 ).

It may be related to water production and water treatment processes in the region where large amounts of electricity are consumed to withdraw, desalinate and treat huge amounts of water.

\subsection{Morals and Environmental Motives}

Based on the information provided by Haya (Service, 2019), In north of Oman every day sewage treatment plants produce more than 100 tons of dry sludge which needs to be utilized. For a year it makes more than 36 thousand tons. It can be assumed, this value correlates to the present population and water consumption value. So if population and water consumption increases, then the production of sludge will increase as well. And it can be projected that by 2022 it will have increased by $52 \%$, making up more than 54.7 thousand tons/year. This proposed system will offer $100 \%$ utilization of the dry waste.

\subsection{Research and Scientific Motivation}

It can be said that this system presented in the paper can give after establishment

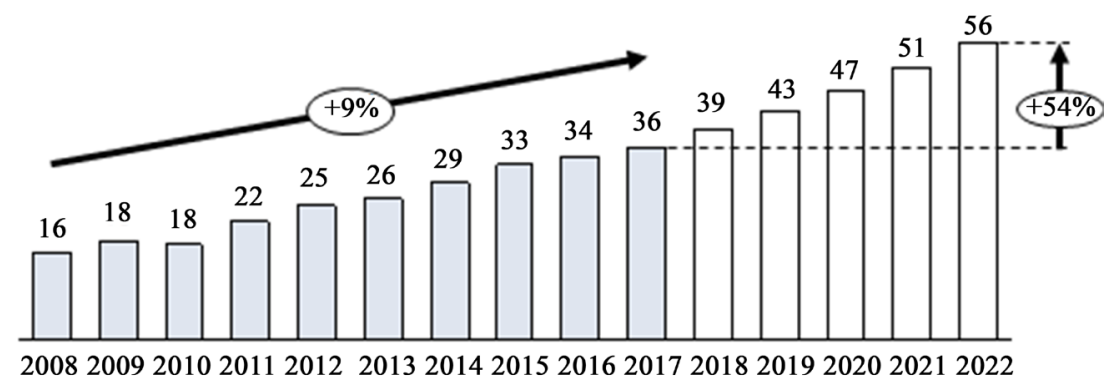

Figure 4. Electricity production.

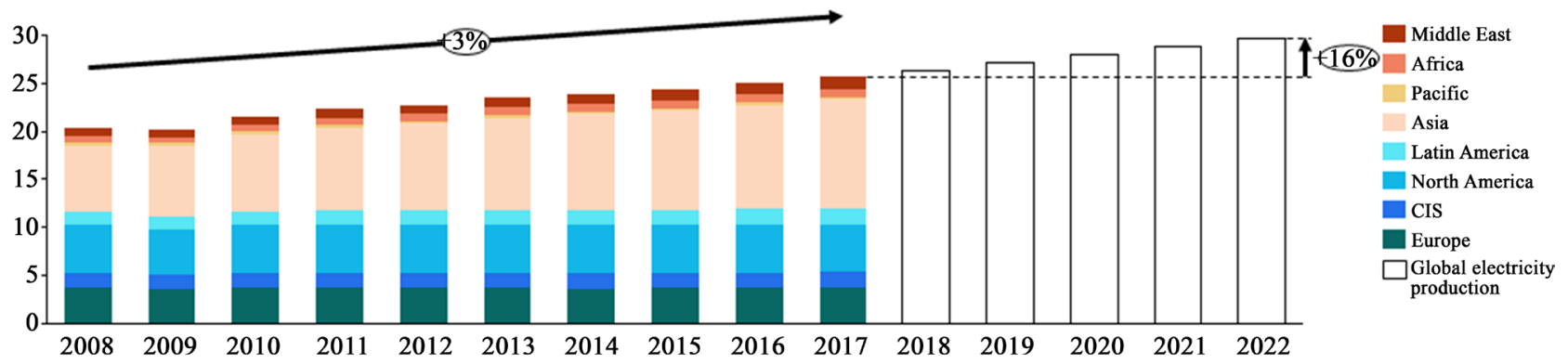

Figure 5. Global electricity production. 
the following research and innovation potentials:

- It can give bio-technology specialists a real operating data from the Omani operating conditions.

- It can give the bio-technology specialists and engineers working in this filed the chance to innovate in building and test better and more efficient equipment and develop Omani branded technologies and industrial techniques.

- It opens up the doors for researchers to experiment new developments in reality.

\section{Sludge Utilization Strategies Review}

From the literature (Barber, 2012; Gnansounou, 2019; Gnansounou \& Alves, 2019; Hublin et al., 2014; Ruan et al., 2019; Yusup et al., 2019; Wellinger et al., 2013; Communities, 2002; Christodoulou \& Stamatelatou, 2016; Baawain et al., 2015; Baawain et al., 2014; Jaffar Abdul Khaliq et al., 2017; Calusinska et al., 2018), there exist different ways to utilize waste and sludge. They include landfilling; composting, processing at gasification and incineration plants, as well as using at biogas plants and co-firing in cement kilns (Calusinska et al., 2018). The last two technologies are considered to be feasible to pursue.

\subsection{Landfilling}

It is one of the strategies of waste and sludge disposal (Sludge, 1997). Historically, landfilling has been the most common method of organized waste disposal and remains so in many places around the world. Landfilling is one of the most cost-efficient ways to dispose of waste, especially in countries with large open spaces. They have fewer fixed or ongoing costs, which is a strong competitive advantage.

At the same time landfills are now widely recognized as being an unsustainable outlet (Kollikkathara et al., 2010; Hall, 1999; Rulkens, 2007) due to concerns over the following:

- Rotting food and other decaying organic waste create methane and carbon dioxide. Landfill gases can get into the surrounding air and soil. Apart from contamination, they may contribute to the increased amount of greenhouse gases in the atmosphere, leading to climate change, disruption of ecosystems, and posing a risk to human health.

- Leachate of the waste and dry solid of sludge containing toxic and materials may get to soils, groundwater and then, potentially, to drinking water. It may lead to a negative impact on human health, reduction of microorganisms in soils, a decrease in groundwater quality, degradation of ecosystems and a decrease in surface water quality.

- Other issues include wildlife disruption, dust, noise, and reduced local property values.

In Oman landfills and landfilling are managed by Beah. Increased amounts of sludge and, as a result, dry solid represent a potential problem for Beah, as it is 
running short of available landfilling sites. Oman government introduced limits for metal concentration in sludge for its utilization and disposal (Al-Musharafi et al., 2013) (see Table 1).

If the concentration of metals exceeds limits, the sludge has to be disposed of in sanitary landfills or other facilities, but only with the prior approval of the Ministry. Sludge which is not being delivered to contractors or users shall either be utilized in an approved manner or be disposed of by the owners in an approved manner.

In order to dump the dry solid of sludge, it is necessary to pay a landfilling tariff and a transportation fee to transfer sludge to the landfilling site. Every megaton of waste is obliged by a tariff, which ranges more than OMR 10/ton. In other countries, landfill tariff is comparable to that in Oman, the highest being in the UK-ranging from OMR 17.7 to OMR 212.2. The figure below shows the published tariffs in some of the European countries (Hogg, 2002) (see Figure 6).

In Northern Oman, more than 54,750 MT of sludge is generated every year. In order to utilize it, the STP owners has to pay OMR \$ for every ton to Beah, which makes OMR \$ per year. Besides, it has to pay for transportation to landfilling sites-about OMR expected to be more than 206,000. And for every ton, the STP owner pays a landfill tax in case it has been introduced. Taking into account the increase in sludge generation these numbers are more than likely to rise, as, in order to provide enough space for landfilling, Beah may start to increase landfilling tariff and cost for utilization. A possible solution is to reduce the amount of wet

Table 1. Limits for metal concentration in sludge for its utilization and disposal in Oman.

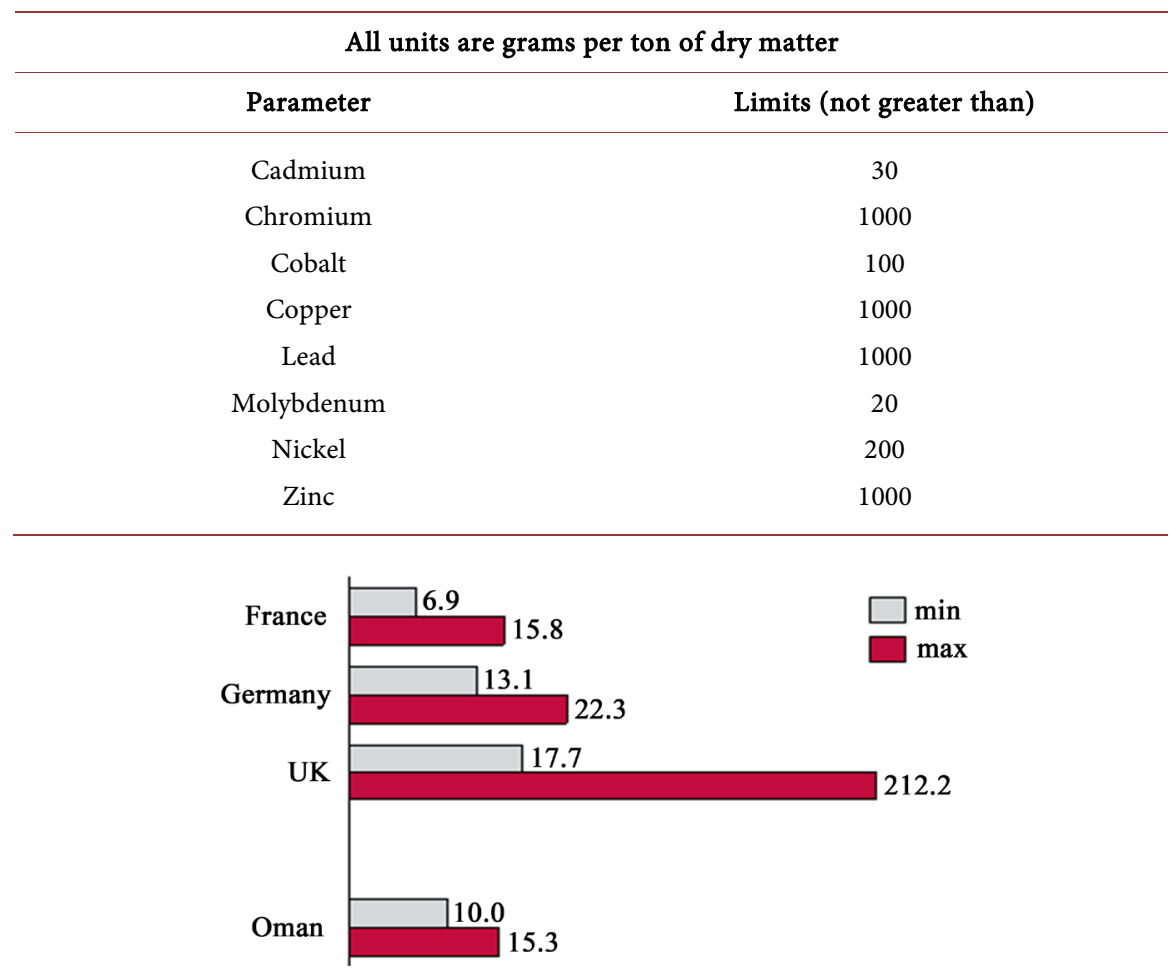

Figure 6. Published landfilled tariffs in some of the European countries. 
content of sludge. This will be effective only if we speak about large amounts of sludge. The diagram visualizes the total annual cost (OMR) of landfilling against the moisture content of the sludge/cake (\%) for 4 T/d (see Figure 7).

The landfill tariff increase is a steady tendency in the EU. In 2010 the majority of countries had a tax level for municipal waste landfilling exceeding OMR 13 per tons of waste. And since then many countries have been increasing the tax rate, so now it is around OMR 26, i.e. a 2-time increase from 2010. It is a measure that governments have to take in order to move up the utilization hierarchy, where landfilling is at the bottom.

\subsection{Burning (Incineration)}

Incineration (see Figure 8) is the process of oxidizing organic sediment to non-

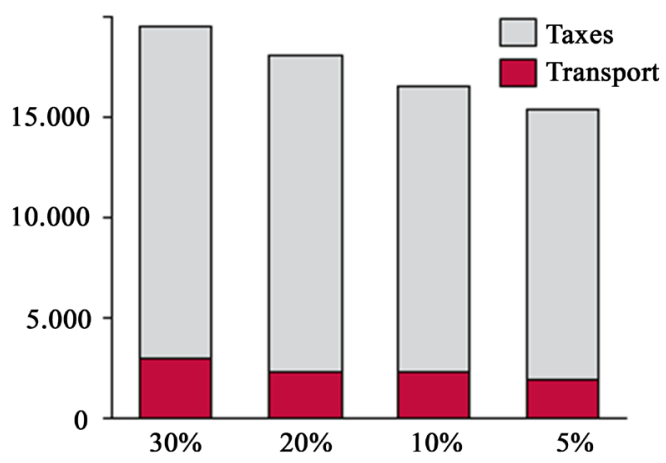

Figure 7. Total annual cost (OMR) of landfilling against the moisture content of the sludge.

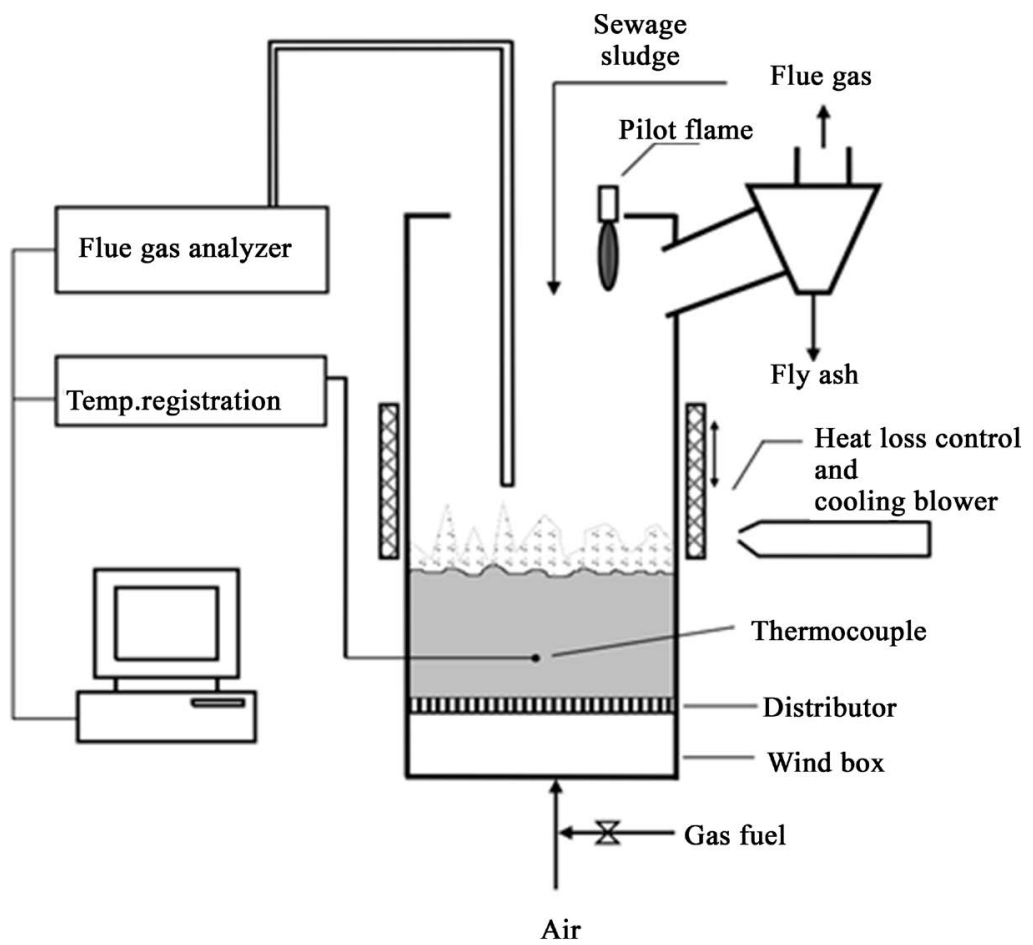

Figure 8. An incineration process of sludge (Wellinger et al., 2013). 
toxic gases, i.e. carbon dioxide, water vapor and nitrogen, and ash. Before the start of the process, sediments should be either mechanically dehydrated or thermally dried (Samolada \& Zabaniotou, 2014).

Sewage sludge is delivered to the incineration plant. There, it is dewatered and dried. Then the sludge undergoes distilling of volatile substances. After that, it goes to the incineration chamber where the organic part of the sludge is burnt, and carbon residues are claimed. The sediment is ignited when the temperature in the chamber reaches $200^{\circ} \mathrm{C}-500^{\circ} \mathrm{C}$. Calcination of the ash part of the sludge is completed by its cooling. The temperature in the furnace during this process is in the range of $700^{\circ} \mathrm{C}-1000^{\circ} \mathrm{C}$. Currently, there are different technologies available: mono-combustion in multiple hearths and fluidized bed furnaces, co-incineration with coal in power plants with other fuels with municipal solid waste and so on.

Sludge incineration (Samolada \& Zabaniotou, 2014) allows reducing a large volume of sludge to a small stabilized ash, which accounts for $10 \%$ of the volume of mechanically dewatered sludge, and thermal destruction of toxic organic constituents. Furthermore, sludge has a high calorific value, which corresponds to that of brown coal, and through incineration, this energy content may be recovered. This technology allows us to control the spread of diseases, recover the precious metals and ensures low fluctuations of temperature and flow rates. Besides, it is relatively easy to implement and operate, as there is a rich experience in the field. However, sludge incineration raises the following concerns (Rulkens, 2007):

- After incineration, up to $50 \%$ of the input dry mass of sewage sludge remains as ash and most of the toxic heavy metals in sludge are retained which complicates ash disposal, because it becomes expensive to dispose and requires special and costly filling sites.

- The nitrogen, chlorine, sulfur, dioxins, furans, etc. presented in sludge are highly toxic even in minute concentration. They can cause skin disease and affect the nerve system. They are released as gaseous pollutants in various forms during combustion, and this necessitates extensive flue gas cleaning to meet strict emission limits normally imposed on waste incineration.

- The net heating value of mechanically dewatered sludge may not be sufficient for auto-thermal combustion, so supplementary fuel may be necessary. And this has a direct impact on the cost of sludge incineration.

- Sewage sludge contains 1 - $4 \mathrm{mg}$ of mercury per kg of dry matter which exists in various compounds. Due to their low boiling temperature, in the combustion furnace, the mercury compounds are readily vaporized and exist in gas form after combustion. However, due to the instability of the mercury compounds in the gaseous form at higher temperatures, more often at above $700^{\circ} \mathrm{C}$ the compounds decompose to form elementary mercury. The elementary mercury is not readily soluble and thus, unlike other heavy metals, is not removed with the ash during post-combustion flue gas treatments. So it may leach and affect the environment. 
All in all, the construction of the incineration plants or upgrade of treatment facilities for co-incineration requires significant capital expenditure. Furthermore, sewage incineration plants tend to have a bad public image.

\subsection{Gasification}

Gasification (see Figure 9) of sewage waste is an old but promising technology for biomass utilization. It is the process of converting a solid fuel into a gas with a significant heat value by treating the solid fuel in a generator with oxygen, air, and steam or by other gasification methods. The main components of the gas are $\mathrm{CO}, \mathrm{CO}_{2}, \mathrm{H}_{2}$ and $\mathrm{N}_{2}$ (comes from air) (Samolada \& Zabaniotou, 2014; Rulkens, 2007).

The most important reactions that take place in the reduction zone of a gasifier between various gaseous and solid reactants are given below. A minus sign indicates that heat is generated in the reaction, a positive sign-that the reaction requires heat (Wellinger et al., 2013).

$$
\begin{gathered}
\mathrm{CO}+\mathrm{CO}_{2} \rightarrow 2 \mathrm{CO}_{2}+164.9 \mathrm{~kJ} / \mathrm{kmol} \\
\mathrm{C}+\mathrm{H}_{2} \rightarrow \mathrm{CO}+\mathrm{H}_{2}+122.6 \mathrm{~kJ} / \mathrm{kmol} \\
\mathrm{C}+2 \mathrm{H}_{2} \rightarrow \mathrm{CH}_{4}+0 \mathrm{~kJ} / \mathrm{kmol} \\
\mathrm{CO}+3 \mathrm{H}_{2} \rightarrow \mathrm{CH}_{4}+\mathrm{H}_{2} \mathrm{O}-205.9 \mathrm{~kJ} / \mathrm{kmol}
\end{gathered}
$$

The product of the process can be burned in a CHP/turbine unit or upgraded (purified) and used for methanol, ethanol or alkenes synthesis. The obligatory condition of the gasification process is the drying of the sludge. The higher the degree of the dry solid, the more efficient is the gasifier's input and the higher is gas heat value (Ongen et al., 2016). If moisture is over $40 \%$ the merits of gasification become questionable (Heidenreich et al., 2016) (see Table 2 and Figure 10).

Gasification of sewage sludge has certain advantages (Vigil, A. \& Tchobanoglous, 1983; Ongen et al., 2016; Samolada \& Zabaniotou, 2014; Yusup et al., 2019;

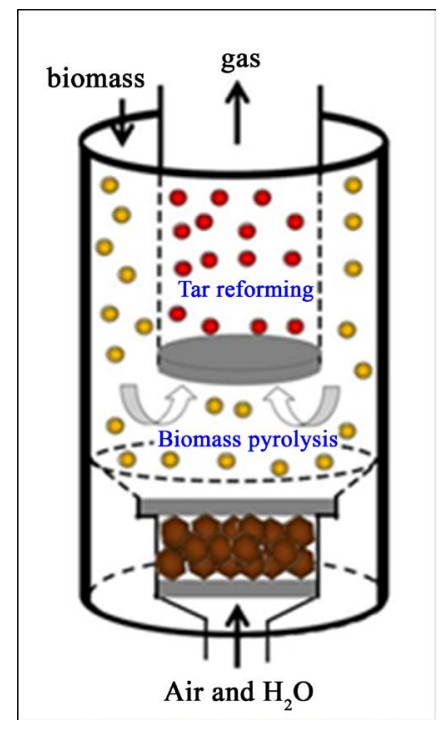

Figure 9. A Gasification process of sewage waste (Wellinger et al., 2013). 
Table 2. Comparison between degree of the dry solid and gasification process output.

\begin{tabular}{cccc}
\hline Fuel moisture (waste) & $20 \%$ & $30 \%$ & $40 \%$ \\
Gasifier's max. output & 100 & 89 & 77 \\
\hline
\end{tabular}

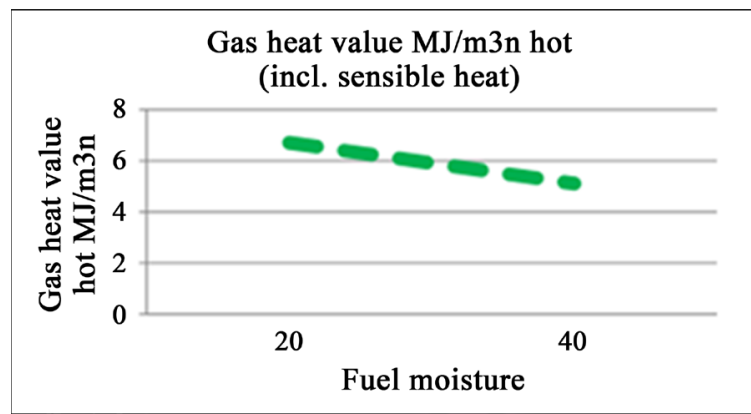

Figure 10. Moisture in fuel highly affects gasification process (Heidenreich et al., 2016).

Heidenreich et al., 2016):

- Reduction of $\mathrm{CO}_{2}$ emissions;

- Cost efficient production of power and heat;

- Alternative to coal-palm leaves, rice hulls or manure;

- Calorific value equal to coal due to the production of syngas $\left(\mathrm{CO}+\mathrm{H}_{2}\right)$;

- Smaller and less expensive gas-cleaning facilities;

- Positive impact on the environment and region economy;

- Gasification takes place in an environment with low levels of oxidizers and large quantities of sulfur and nitrogen oxides, which prevents the formation of dioxins;

- The process allows to produce bio-char, which is rich in $\mathrm{P}$ content, that can be used as a fertilizer, given there are no heavy metals in the content;

At the same time, gasification of sewage sludge has some issues that need to be taken into consideration before choosing this method of utilization (Vigil \& Tchobanoglous, 1983; Ongen et al., 2016; Samolada \& Zabaniotou, 2014; Yusup et al., 2019; Heidenreich et al., 2016):

- The gas produced during gasification is flammable;

- There is a risk that dust in contact with the gas can explode;

- There is a risk of gas poisoning (CO and so on) in case of an accident;

- Heat recovery is mostly used for drying;

- Installation and running of the gasification plants requires high capital expenditure;

- The by-product of the gasification process is bio-char, a fertilizer which at the present does not have a large market.

\subsection{Composting}

Composting (Rehl \& Müller, 2011; Sludge, 1997; Verstraete et al., 2007; Venkiteshwaran et al., 2016; Goswami et al., 2016; Baawain et al., 2015) of wastewater residual is a bio-thermal aerobic process that decomposes the organic portion of 
the residuals. The composting process reduces the organic material in the residual by approximately 25 percent. During composting the heat generated by the decomposition of the organic portion of the residuals reduces the moisture content of the residual, stabilizes it and renders the residual harmless by transforming it into a usable bi-solid (Rulkens, 2007).

Based on its content of nitrogen, phosphorus, calcium, magnesium, sulfur, etc. sludge shows good fertilizer properties. But sewage sludge should be completely and properly processed before being used in agriculture. When properly treated and processed, sewage sludge becomes bio-solids. Table 3 shows typical properties of untreated and digested sewage sludge (Bonten et al., 2014).

So it can be seen that sewage sludge treatment allows getting the product rich in nutrients (3.0 compared to 2.5), phosphorus (2.5 compared to 1.6).

Sewage sludge may be further "upgraded" to get organic-mineral fertilizers (OMF) (Kominko et al., 2018). They are rich in nutrients and microelements. OMFs are produced by adding to dry sewage sludge mineral fertilizers in order to increase nutrient con. Sludge recycling as a fertilizer has several advantages, which include the return of the organic materials into the bio-cycle. Sludge also replaces the application of artificial fertilizers whose production also requires a lot of energy.

Selling sludge as a fertilizer is becoming popular in developed countries (Eggerth et al., 2007; Christodoulou \& Stamatelatou, 2016). In the UK, France, Germany and other developed countries they have sludge composting fertilizer available for sale. Eastern treatment plant in Melbourne of Australia treats $1.2 \times$ $10^{4} \mathrm{~m}^{3}$ dry sludge per year as soil amendments to sell to nurseries. In China, Shenzhen has mixed sludge composting and animal manure for sale.

So Oman may consider this option as well. Sludge can be fully composted and then sold as bulk compost or upgraded with organic-mineral fertilizer. However, it is difficult to determine the profitability of the approach. Besides, sludge dewatering and then transportation further complicates the process and increases the costs. So it is questionable if straight composting of sludge has any economic success.

It is necessary to point out that selling bio-char as a fertilizer is risky, as it is a new type of business. Also, additional research is needed to assess the profitability of this market, the content of heavy metals in the sewage sludge in Oman.

Table 3. Properties of untreated and digested sewage sludge.

\begin{tabular}{ccc}
\hline Item (\% dry weight) & Untreated primary sludge & Digested primary sludge \\
\hline Total dry solids & 5 & 10 \\
Volatile solids & 65 & 40 \\
$\mathrm{~N}$ & 2.5 & 3.0 \\
$\mathrm{P}_{2} \mathrm{O}_{5}$ & 1.6 & 2.5 \\
$\mathrm{~K}_{2} \mathrm{O}$ & 0.4 & 1 \\
\hline
\end{tabular}


The existing studies (Jaffar Abdul Khaliq et al., 2017; Baawain et al., 2015; Baawain et al., 2014) show that because of the difficulties associated with the application of compost in comparison with competing products, the actual size of the market is still relatively small. The same situation may exist in Oman as well.

Furthermore, in the recent past, the application of sludge on agricultural land has met a lot of setbacks due to the presence of heavy metals in the sludge (Hall, 1999; Communities, 2002). To regulate the use of sewage sludge on agriculture, many countries have introduced limit concentrations for heavy metals and the frequency of application (Bonten et al., 2014; Kominko et al., 2018).

From Table 4, it can be seen that the limits for heavy metal content range depending on the application. For agricultural exploitation limits for heavy metals, concentrations are very low, as they may get into the food chain and affect the health and well-being of humans and animals. It is possible to say that due to the increasing volumes of sludge and a still more pressing problem of sludge utilization, these limits may become even more stringent. So it is possible to presume, that concern over risks from heavy metals and organic contaminants in the sludge, and caution over the addition of nitrogen- and phosphorus-rich manure to land, will continue to be a major factor in limiting the use of sludge as fertilizer.

\subsection{Sludge Co-Processing in Cement Kilns}

Co-firing of sludge in cement kilns may be regarded as a profitable way of sludge utilization. The technology may sound new to Oman, but it is used actively in China (Li et al., 2013). There, in 2008 was built a system for ejecting wet SS to cement kiln with clinker capacity about $2500 \mathrm{t} / \mathrm{d}$. It is possible to utilize 100 ton SS per day using this system.

Sludge from WWTP is transported to a reservoir of the cement plant and then fed directly to the inlet of the kiln through high-pressure pumps (see Figure 11).

Heavy metals in the contents of sludge are incorporated in the clinker, while the volatile and semi-volatile materials accumulate in cement kiln dust. It is

Table 4. Limits for heavy metal content range.

\begin{tabular}{cccc}
\hline & \multicolumn{2}{c}{ Soil fertilization, land reclamation } & $\begin{array}{c}\text { Agro-technical } \\
\text { composting. Drainage } \\
\text { and reclamation }\end{array}$ \\
\cline { 2 - 4 } & Agricultural exploitation & $\begin{array}{c}\text { Non-agricultural } \\
\text { exploitation }\end{array}$ & \\
\cline { 2 - 4 } mg/kg d.m. & 1500 \\
Lead (Pb) & 500 & 1000 & 50 \\
Cadmium (Cd) & 10 & 25 & 2500 \\
Chromium & 500 & 1000 & 2000 \\
Copper $(\mathrm{Cu})$ & 800 & 1200 & 500 \\
Nickel $(\mathrm{Ni})$ & 100 & 200 & 25 \\
Mercury $(\mathrm{Hg})$ & 5 & 10 & 5000 \\
Zinc $(\mathrm{Zn})$ & 2500 & 3500 & \\
\hline
\end{tabular}




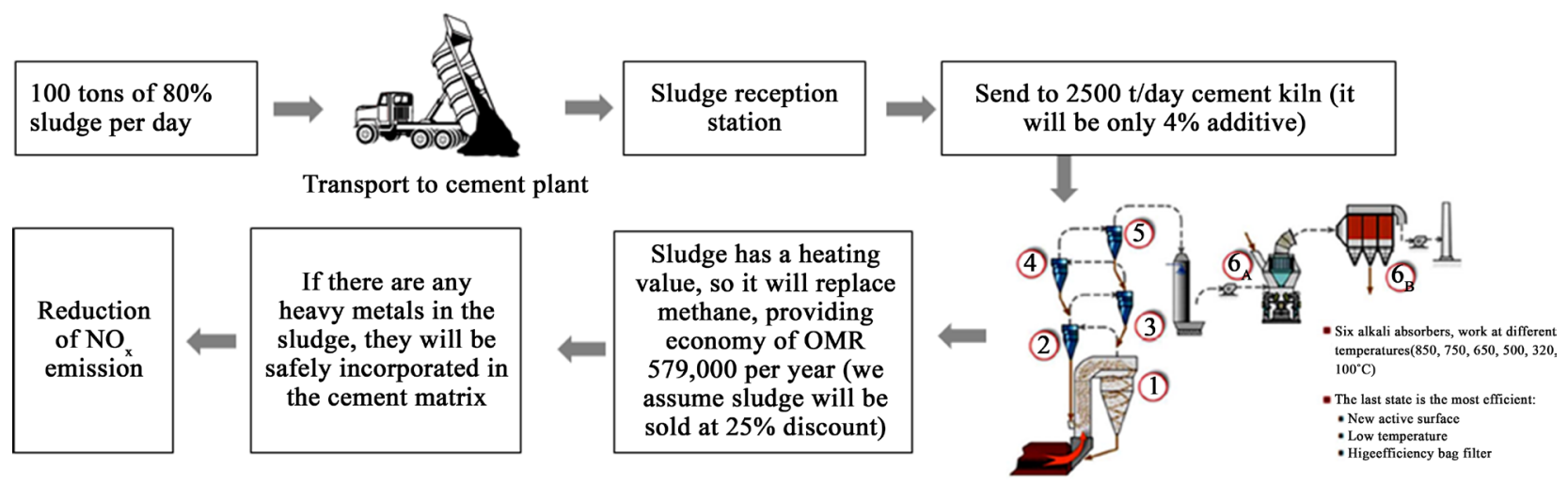

Figure 11. The overview of the co-firing process in the cement plant.

proved by the research conducted by the University of Tuzla (Cipurkovic et al., 2014). They analyzed contents of cement produced at the Cement Factory of Lukavac and found out that non-volatile metals generally tend to be incorporated into the clinker, while the lower part, especially volatile and semi-volatile metals (cadmium, mercury), accumulates in the cement dust. Volatile and semi-volatile metals, as well as fine particles of cement dust, possibly, depending on the efficiency of the existing filters in the factory, can broadcast the gaseous products. These properties can have a significant impact on the distribution of metals at high temperatures in the sintering process. The distribution of elements in different streams in the process of sintering indicates that most of the trace elements get incorporated in the mineral phases of clinker. Due to the incorporation of heavy, toxic metals in the clinker minerals, they are entered in the cement and concrete later in which to linger for many years, thus, preventing or reducing their negative impact on the environment.

Another research has shown that presently used secondary input materials in some cases result in a slight increase in trace element concentrations of cement (Achternbosch et al., 2005; Achternbosch et al., 2003). However, a general assessment of the use of wastes in cement production and of its impact on trace element input cannot be made. Furthermore, future developments can hardly be estimated. The study has also shown that the mobilization of trace elements from concrete components during service life is negligibly small. After demolition, an increased trace element mobilization is conceivable under certain assumptions.

However, studies at the Huaxin cement plant (Li et al., 2013) showed that sludge could be disposed of in the cement kilns with no negative effect on clinker quality and environment. There were made comparisons of clinker quality on a normal production line (Kiln 1) and on a sludge disposing line (Kiln 2).

Figure 12 shows that there are minor differences in the clinker composition, which proves that sludge does not affect clinker quality.

Furthermore, the alkaline atmosphere of the cement kiln system and the high turbulence makes the acidic gas, such as $\mathrm{SO}_{2}, \mathrm{HCl}$, be neutralized and reduces the emission. The system also makes most of the HM gas emission far below the 


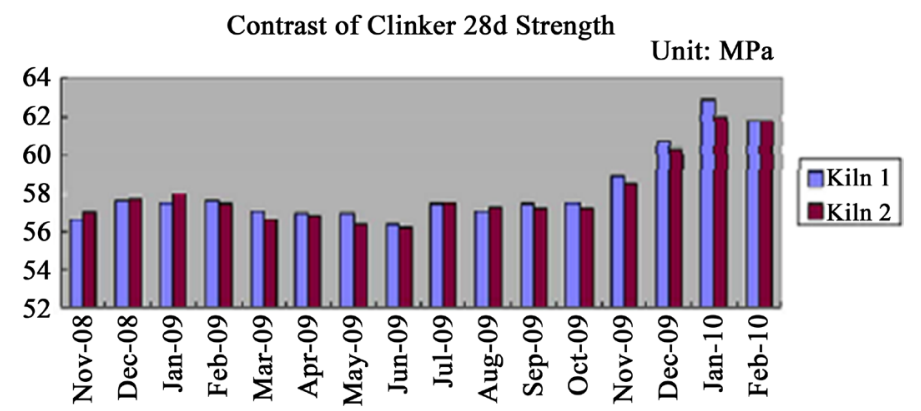

Figure 12. Co-Processing Sewage Sludge in Cement Kiln in China (Li et al., 2013).

limitation, with the exception of mercury and thallium.

When fired in cement kilns, sludge can be used as an alternative fuel, replacing natural gas (Al Seadi et al., 2013; Kratzeisen et al., 2010). Components of sludge have a heating value and allow to save at least more than half million Omani Rials per year, which is equivalent to $11,463,600 \mathrm{~m}^{3}$ per year.

The implementation of this technology in Oman is advantageous, as sewage treatment plants in Oman produce sludge with a greater percentage of the dry solid than in China as shown from the data provided by Haya.

Sludge co-firing requires relatively inexpensive equipment upgrade-around half a million Omani Rials $\pm 20 \%$ (this by surveying the internet for the off-shelf equipment suitable to the system in Oman Cement Company). These resources are needed to obtain and install bag filters to capture harmful dust and a wet-scrubber to produce cleaned and dust-free gas.

An independent operator can service both WTP owners and cement plants for cost-effective sludge utilization. Taking into account the transportation costs of sludge from WTP to a cement plant, salaries and overhead costs. The total revenue of the operator is made up of the annual revenue from STP owner, selling sludge as a fuel for a cement plant as a replacement for natural gas with a 25\%-discount.

From the performed analysis it is possible to say that cement plants can be used for both sewage sludge disposal or co-processing for the environment and natural fossil fuel saving. Oman has suitable conditions for effective sludge disposal, as dry solid of sludge is higher than in other countries. Sludge serves as an alternative fuel to natural gas and allows decreasing expenses on natural gas.

\subsection{Biogas Production}

The rule of biogas production is attractive idea in the view of sustainable development (Calusinska et al., 2018; Hublin et al., 2014; Valenti et al., 2018; Su et al., 2015; Scarponi et al., 2015; Han et al., 2016; Heyer et al., 2016; Baeyens et al., 2016; Törnwall et al., 2017; Goswami et al., 2016; Klocke et al., 2007; Sillas-Moreno et al., 2019; Campanaro et al., 2018; Patterson et al., 2011; Rehl \& Müller, 2011; Treichel \& Fongaro, 2019; Kovács et al., 2013; Guo et al., 2019; Heezen et al., 2013; Kougias et al., 2017; Poeschl et al., 2012b; Poeschl et al., 2012a; Yanuka-Golub et al., 2019; Fontana et al., 2016; Sgroi et al., 2015; Luo et 
al., 2016; Angelidaki et al., 2019; Nguyen et al., 2019; Yusup et al., 2019; Rachbauer et al., 2016; Schnürer, 2016; Mathew et al., 2015; Regattieri et al., 2018; Wellinger et al., 2013; Scarponi et al., 2016; Kratzeisen et al., 2010; Casson Moreno et al., 2016; Al Seadi et al., 2013). It has been estimated that in the last 10 years biogas production triplicated, resulting in accumulative growth on the number of related facilities (Casson Moreno et al., 2016). This clearly indicates the amount of work already established in this filed.

Anaerobic digestion $(\mathrm{AD})$ is a microbe-driven process of biomass decomposition to $\mathrm{CH}_{4}(60 \%$ - 70\%) (Yanuka-Golub et al., 2019; Goswami et al., 2016; Kim et al., 2019; Prabhu \& Mutnuri, 2016) and $\mathrm{CO}_{2}$ with good cost-effective energy production through Microbial resource management (MRM) (Calusinska et al., 2018; Verstraete et al., 2007; Read et al., 2011; Wang et al., 2019). Anaerobic digestion already providing the world by an estimated figure of around 10,000 MW of power (Verstraete, 2015). All these facts are improving the confidence level of AD technologies with higher trust for energy production establishment here in Oman.

A number of studies explored the microbial community ecology of $\mathrm{AD}$ with great insights of the structure, dynamics and functionality of microbial communities (Kirkegaard et al., 2017; De Vrieze et al., 2015; Abendroth et al., 2015; Werner et al., 2011; Fontana et al., 2016; Luo et al., 2016; Campanaro et al., 2018) covering the factors affecting microbial community in AD (Mathew et al., 2015; Kim et al., 2019; Jimenez et al., 2013; Astals et al., 2014); Figure 13 and Figure 14 are examples.

From literature it can be concluded that commonly the largest incensement in production which can be considered economically viable from the operational point of view is the first 72 hours of AD. Figure 15 and Figure 16 show and

\begin{tabular}{|c|c|c|c|}
\hline & FW & $\mathrm{HF}$ & TP \\
\hline $\mathrm{C}(\%$, dry w/w) & $49.2(1.3)^{\mathrm{a}}$ & $49.5(0.5)$ & $41.7(0.2)$ \\
\hline $\mathrm{H}(\%$, dry $w / w)$ & $7.1(0.2)$ & $6.9(0.1)$ & $6.3(0.1)$ \\
\hline $\mathrm{O}(\%$, dry $w / w)$ & $44.4(0.3)$ & $38.1(0.5)$ & $51.3(0.1)$ \\
\hline $\mathrm{N}(\%$, dry w/w) & $3.7(0.6)$ & $5.4(0.2)$ & $0(0)$ \\
\hline$S(\%$, dry w/w) & $0(0)$ & $0(0)$ & $0(0)$ \\
\hline $\mathrm{C}: \mathrm{N}$ ratio & 13.3 & 9.2 & n.a. \\
\hline CHONS & 104.4 & 99.9 & 99.3 \\
\hline $\mathrm{Co}(\mathrm{mg} / \mathrm{L})$ & $0.004(0)$ & $0.006(0.001)$ & $0.002(0)$ \\
\hline $\mathrm{Cr}(\mathrm{mg} / \mathrm{L})$ & $0.028(0)$ & $0.046(0)$ & $0.016(0)$ \\
\hline $\mathrm{Cu}(\mathrm{mg} / \mathrm{L})$ & $0.424(0.001)$ & $1.984(0.003)$ & $0.032(0.002)$ \\
\hline $\mathrm{Fe}(\mathrm{mg} / \mathrm{L})$ & $3.860(0.003)$ & $14.120(0.03)$ & $0.652(0.009)$ \\
\hline $\mathrm{Mn}(\mathrm{mg} / \mathrm{L})$ & $0.730(0.001)$ & $5.660(0.009)$ & $0.038(0.004)$ \\
\hline $\mathrm{Ni}(\mathrm{mg} / \mathrm{L})$ & $0.090(0.001)$ & $0.256(0.002)$ & $0.066(0.002)$ \\
\hline $\mathrm{Zn}(\mathrm{mg} / \mathrm{L})$ & $2.100(0.003)$ & $16.460(0.031)$ & $0.410(0.008)$ \\
\hline $\mathrm{Mo}(\mathrm{mg} / \mathrm{L})$ & $0.036(0.002)$ & $0.126(0.001)$ & $0.024(0.001)$ \\
\hline $\mathrm{W}(\mathrm{mg} / \mathrm{L})$ & - & - & - \\
\hline Total solids $(\mathrm{g} / \mathrm{L})$ & $111.8(0.9)$ & $61.7(1.1)$ & $17.0(0.2)$ \\
\hline Volatile solids (g/L) & $103.2(0.9)$ & $55.3(1.0)$ & $16.2(0.3)$ \\
\hline Total COD $(\mathrm{g} / \mathrm{L})$ & $144.3(5.0)$ & $92.6(4.7)$ & n.a. \\
\hline Soluble COD $(\mathrm{g} / \mathrm{L})$ & $89.8(2.1)$ & $26.7(0.1)$ & n.a. \\
\hline
\end{tabular}

Figure 13. An example factors affecting microbial community in AD which studied (Kim et al., 2019). 


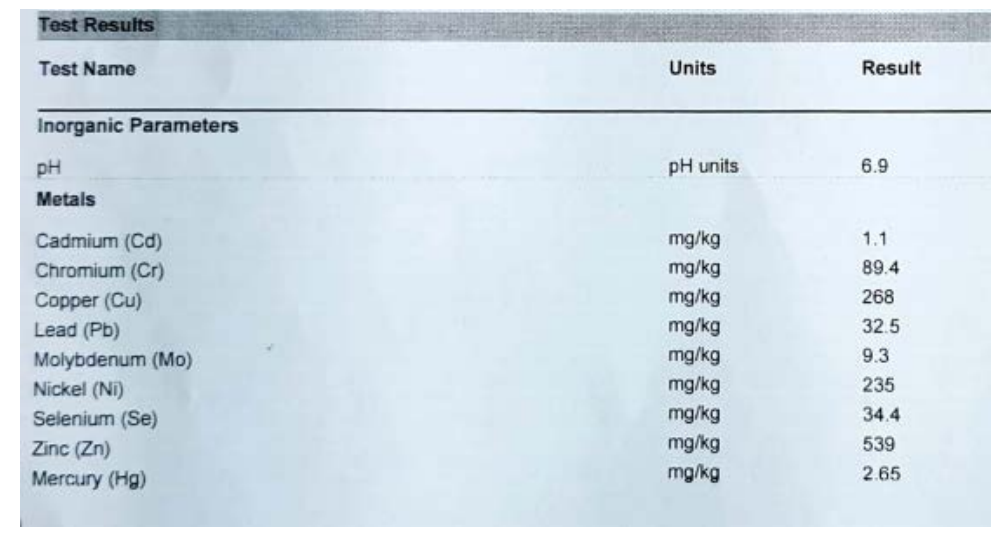

Figure 14. Example test collected from local STP.

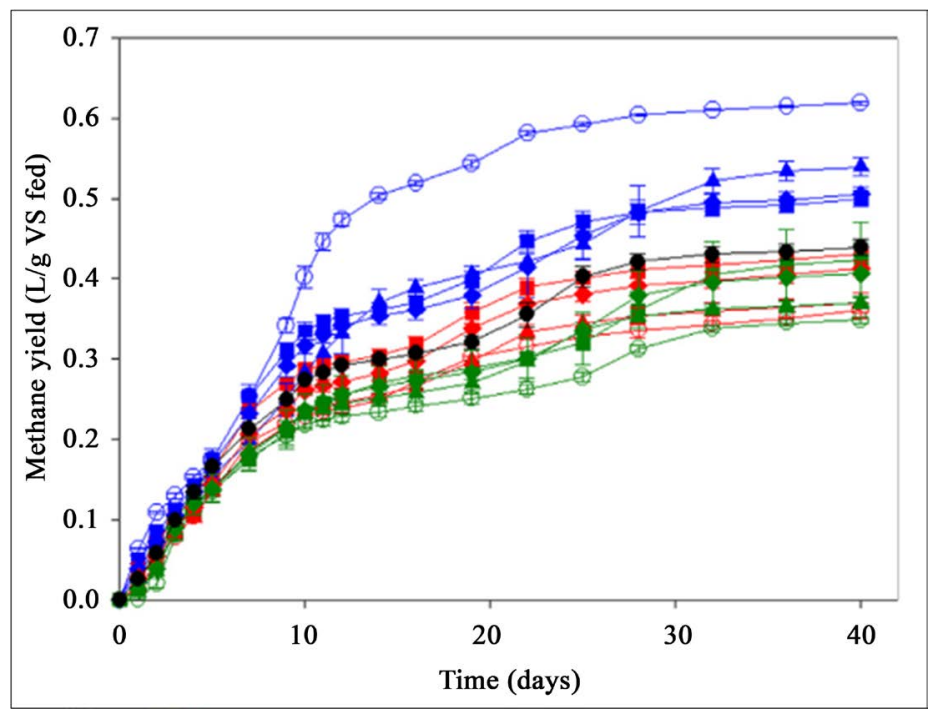

Figure 15. Anaerobic digestion over time for Methane yield (Kim et al., 2019).

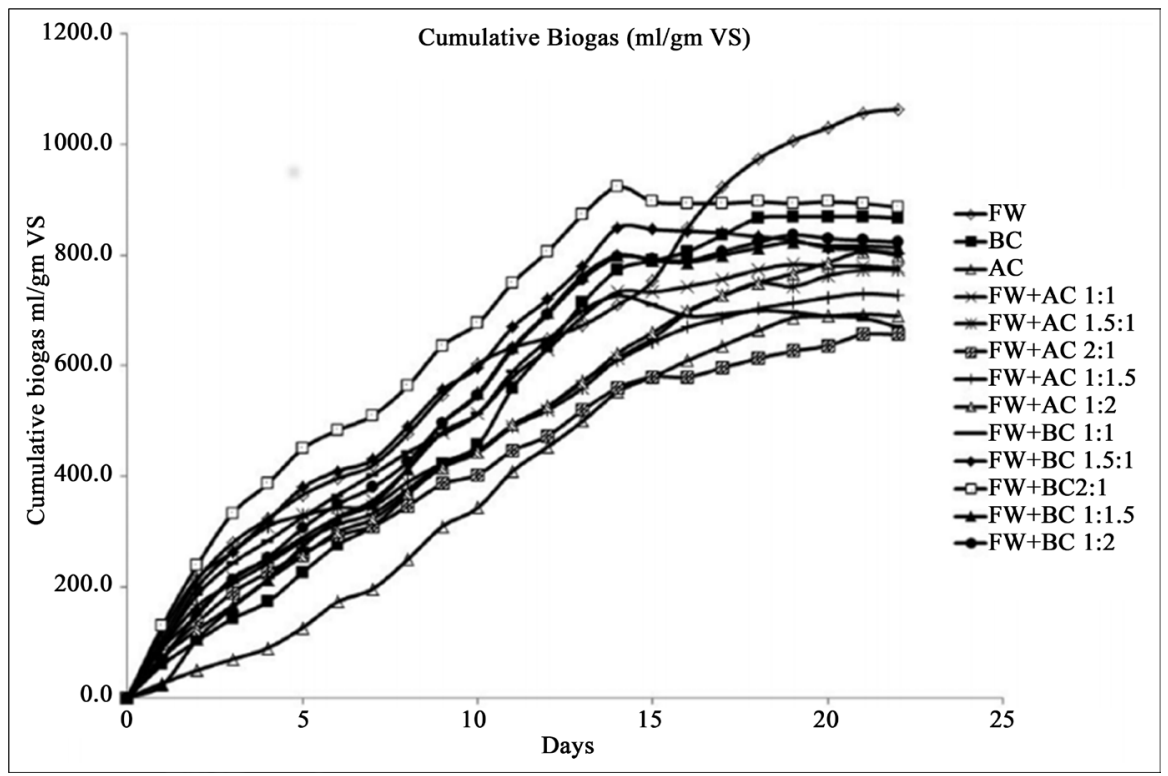

Figure 16. Anaerobic digestion over time cumulative biogas (Prabhu \& Mutnuri, 2016). 
examples for methane production evaluations:

Filed investigation on different operation conditions of producing biogas from thickened slug from sewage treatment plant was studied in Luxembourg and Belgium with good results to encourage such a project (Calusinska et al., 2018). In Europe only more than 13800 biogas plants were running at the end of 2012 (Casson Moreno et al., 2016). It may considered as an operation risk meditation of establishing such an entity in Oman that optimal operating microbial conditions has been suggested (De Vrieze \& Verstraete, 2016; Wang et al., 2019). Never the less; the Omani operating conditions need to be optimized in term of engineering work. Further good news that methods are introduced and tested to improve the quality of the biogas produced by AD process (Yanuka-Golub et al., 2019) with enhanced process stability and performance (Rajagopal et al., 2013; Kougias et al., 2017; Rachbauer et al., 2016).

In relation to operation safety of the biogas production need to be addressed. Literatures have been showing the type of safety analysis obtained for this industrial sector (Heezen et al., 2013; Riviére \& Marlair, 2010) and see-through emerging risk issues and the control measures (Casson Moreno et al., 2016; Moreno \& Cozzani, 2015; Scarponi et al., 2015; Scarponi et al., 2016). According to the literature the lessons learnt for past accident analysis in biogas production and upgrading could be summarized as following:

- Linked to maintenance errors and errors in design.

- Linked to occupational health and safety practice.

- In terms of environmental impact of such a project, there are published studies which provide basic data required for identification and mitigation of emission in biogas production and utilization, including the evaluation of environmental and public health impacts of biogas technology options (Poeschl et al., 2012a; Poeschl et al., 2012b). Such a project in Oman should be in compliance with ISO 14000 standards. In the proposed project the environmental impact assessment seems promising from the literature as the project is proposing to utilize the produced bio-gas in CHP generators to generate electricity.

- Biogas plants represent another way of sludge disposal. It is quite expensive to build and operate, however it has the potential to generate good cash flow if biogas is needed to produce electricity at peak time.

- 100 tons of $80 \%$ dry solid is transported from sewage treatment plants to a biogas plant. Sludge is put in the biogas reactor where anaerobic digestion takes place. It results in the production of $37,500 \mathrm{~m}^{3}$ of biogas per day, where the content of methane is $59 \%$. Then biogas is stored in gasholders. When peak electricity is required, biogas is burnt in the CHP cogeneration machine. It allows producing $\approx 85,600 \mathrm{~kW}$ h of electricity per day (see Figure 17 ).

- The cost of the construction of a biogas plant depends on the input amount of sludge per day. The more it is, the higher the capital expenses will be (see Figure 18). 


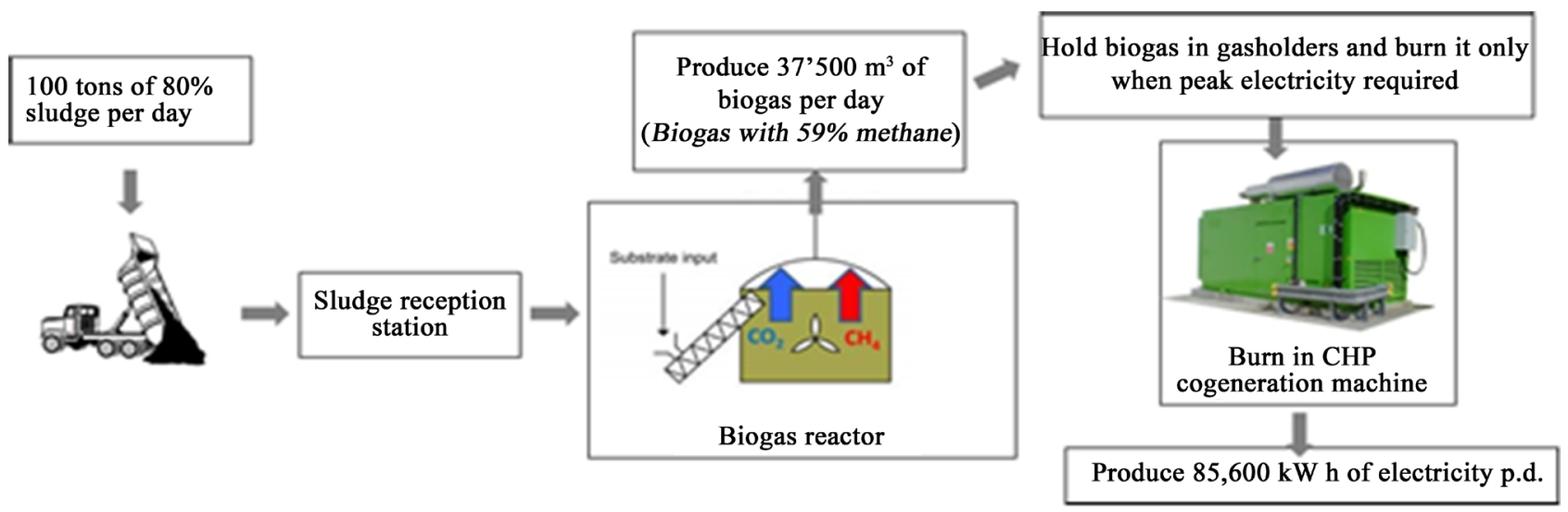

Figure 17. Overview of biogas production and utilization.

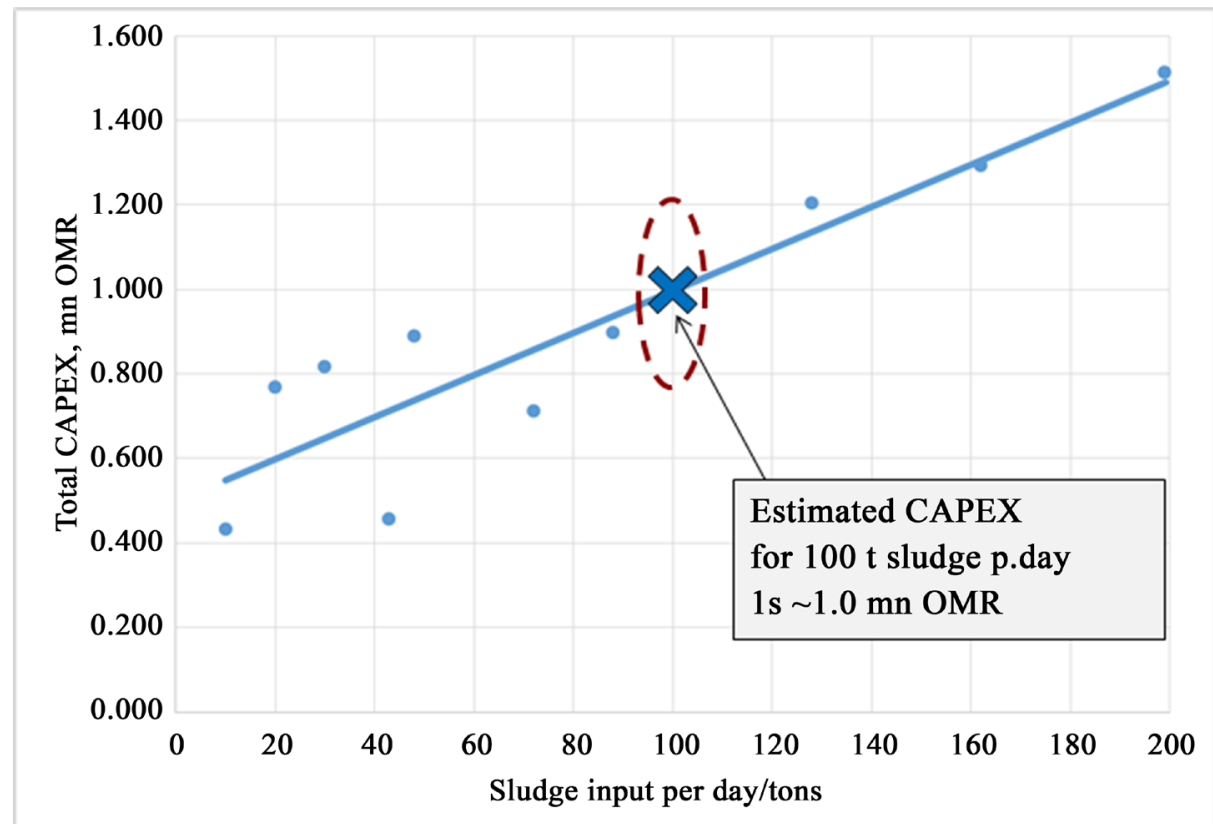

Figure 18. The cost projection is sourced form (Sgroi et al., 2015; Valenti et al., 2018).

- From Figure 18, it can be seen that the input amount of $100 \mathrm{t}$ of sludge per day will require around OMR $1 \times 10^{6}$ plus the design cost, commissioning and the start up in order to construct a biogas plant in Northern Oman. However, these expenses do not cover costs for plant design.

- The digested slurry created during biogas production is known as Digestate. It goes into a post-digester reactor and from there further into storage tanks. Digested slurry from the biogas reactor may be also burnt at the cement plant.

\section{Explored Options and Technology Investigation Result Summary}

\subsection{Summary Table}

Table 5 presents advantages and disadvantages of the assessed technologies. 
Table 5. Summary of the study which presents the advantages and disadvantages of the examined technologies.

\begin{tabular}{|c|c|c|c|c|c|c|}
\hline Technology & Landfilling & $\begin{array}{l}\text { Co-firing in } \\
\text { cement kilns }\end{array}$ & Incineration & Biogas production & Gastification & Composting \\
\hline Advantages & $\begin{array}{l}\text { - Easy } \\
\text { - Fewer costs }\end{array}$ & $\begin{array}{l}\text { - No emissions of } \\
\text { - Seavy metals } \\
\text { - High calorific } \\
\text { value } \\
\text { - No influence on } \\
\text { the environment } \\
\text { or clinker quality } \\
\text { - No threat for a } \\
\text { human } \\
\text { - The least } \\
\text { expensive and } \\
\text { cost-demanding } \\
\text { technology }\end{array}$ & $\begin{array}{l}\text { - Easy to implement and } \\
\text { operate } \\
\text { - Reduction in the } \\
\text { volume of sludge } \\
\text { - Control of spread of } \\
\text { diseases } \\
\text { - Recovery of precious } \\
\text { metals }\end{array}$ & $\begin{array}{l}\text { - Safe utilization } \\
\text { - Short payback } \\
\text { period } \\
\text { - Electricity } \\
\text { generation } \\
\text { - Energy } \\
\text { independence } \\
\text { - Different } \\
\text { revenue flows }\end{array}$ & 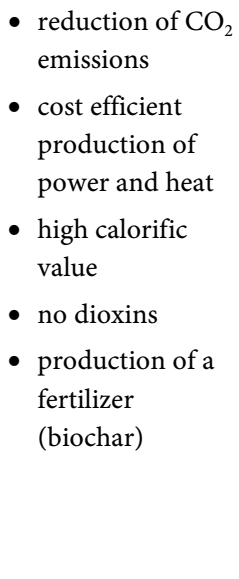 & $\begin{array}{l}\text { - A rich } \\
\text { content of } \mathrm{P} \\
\text { and } \mathrm{K} \\
\text { - A substitute } \\
\text { to artificial } \\
\text { fertilizers }\end{array}$ \\
\hline Disadvantages & $\begin{array}{l}\text { - Soil contamination } \\
\text { - Greenhouse gases } \\
\text { emission } \\
\text { - Leachate of toxic } \\
\text { materials to soils, } \\
\text { groundwaters and } \\
\text { drinking water } \\
\text { - Lack of sites for } \\
\text { landfilling } \\
\text { - High } \\
\text { transportation cost }\end{array}$ & $\begin{array}{l}\text { - Equipment } \\
\text { upgrade at a } \\
\text { cement plant is } \\
\text { needed } \\
\text { - Competent } \\
\text { operators are } \\
\text { needed to control } \\
\text { the process }\end{array}$ & $\begin{array}{l}\text { - toxic metals are } \\
\text { retained after the } \\
\text { buring } \\
\text { - utilization of toxic } \\
\text { metals is expensive } \\
\text { - dioxins, furans, } \\
\text { chlorine are released as } \\
\text { gaseous pollutants } \\
\text { - Heating value of the } \\
\text { sludge is not enough } \\
\text { for auto-thermal } \\
\text { combustion } \\
\text { - Mercury in sludge is } \\
\text { not removed with ash } \\
\text { - Expensive to build }\end{array}$ & $\begin{array}{l}\text { - Expensive to } \\
\text { build } \\
\text { - Competent } \\
\text { operators are } \\
\text { needed to run } \\
\text { the plant } \\
\text { - Heavy metals in } \\
\text { the content may } \\
\text { reduce revenues } \\
\text { - High } \\
\text { transportation } \\
\text { costs if there are } \\
\text { heavy metals in } \\
\text { the sludge }\end{array}$ & $\begin{array}{l}\text { - flammable gas } \\
\text { - a risk of } \\
\text { explosion if the } \\
\text { gas is in contact } \\
\text { with the dust } \\
\text { - a risk of CO gas } \\
\text { poisoning } \\
\text { - heat recovery is } \\
\text { used for drying } \\
\text { - high capital } \\
\text { expenditure }\end{array}$ & $\begin{array}{l}\text { - profitability is } \\
\text { hard to } \\
\text { determine } \\
\text { - High costs of } \\
\text { sludge } \\
\text { transportatio } \\
\mathrm{n} \\
\text { - Heavy metals } \\
\text { may be in the } \\
\text { content, } \\
\text { difficult to } \\
\text { examine } \\
\text { - Declining } \\
\text { popularity }\end{array}$ \\
\hline
\end{tabular}

\subsection{Proposed Utility Model}

The Recycling system (see Figure 19) for dry waste from Sewage Treatment Plant (STP) is expected to operate in Omani operation conditions and GCC in future. The system will work in series as following:

1) The dray waste will be delivered from the STP to the bio-gas plant.

2) In the bio-gas plant the dray waste will be fed to biological reactors where Methane gas $\left(\mathrm{CH}_{4}\right)$ will be produced from the reactors. The reaction time is 72 hours/cycle (reaction cycle is from the time the reactor fed until the discharge).

3) From the reactor will expect two types of products:

a) Methane gas which will go to treatment unit for purification and upgrade. and

b) Digested slurry which will go to mechanical shaping unit.

4) The methane (which is the first product from the reactor) will go after the treatment unit to biogas storage unit then to CHP electricity generators to generate electricity which is sold to end user. 


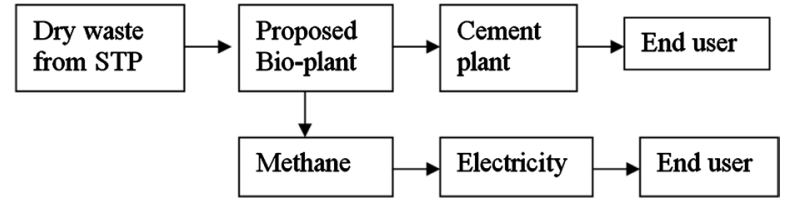

Figure 19. Holistic view of how the recycling system works.

5) The digested slurry (the second product from the reactors) will be transported to a cement plant after coming out of the mechanical shaper.

6) The cement plant will have a feeding system to feed the digested slurry to the clinker where the slurry will be cooked with the limestone in $1400^{\circ} \mathrm{C}$. This process will reduce the amount of gas needed to heat up the clinker which will introduce energy saving to the cement plant. Also cooking the slurry with the limestone will reduce the amount of NOX's gases produced from normal cement production. Also, in the cement plant the proposed system will integrate wet scrubbers into the cement production system to remove any dust from exhaust gases.

\subsection{Process Flow Diagram}
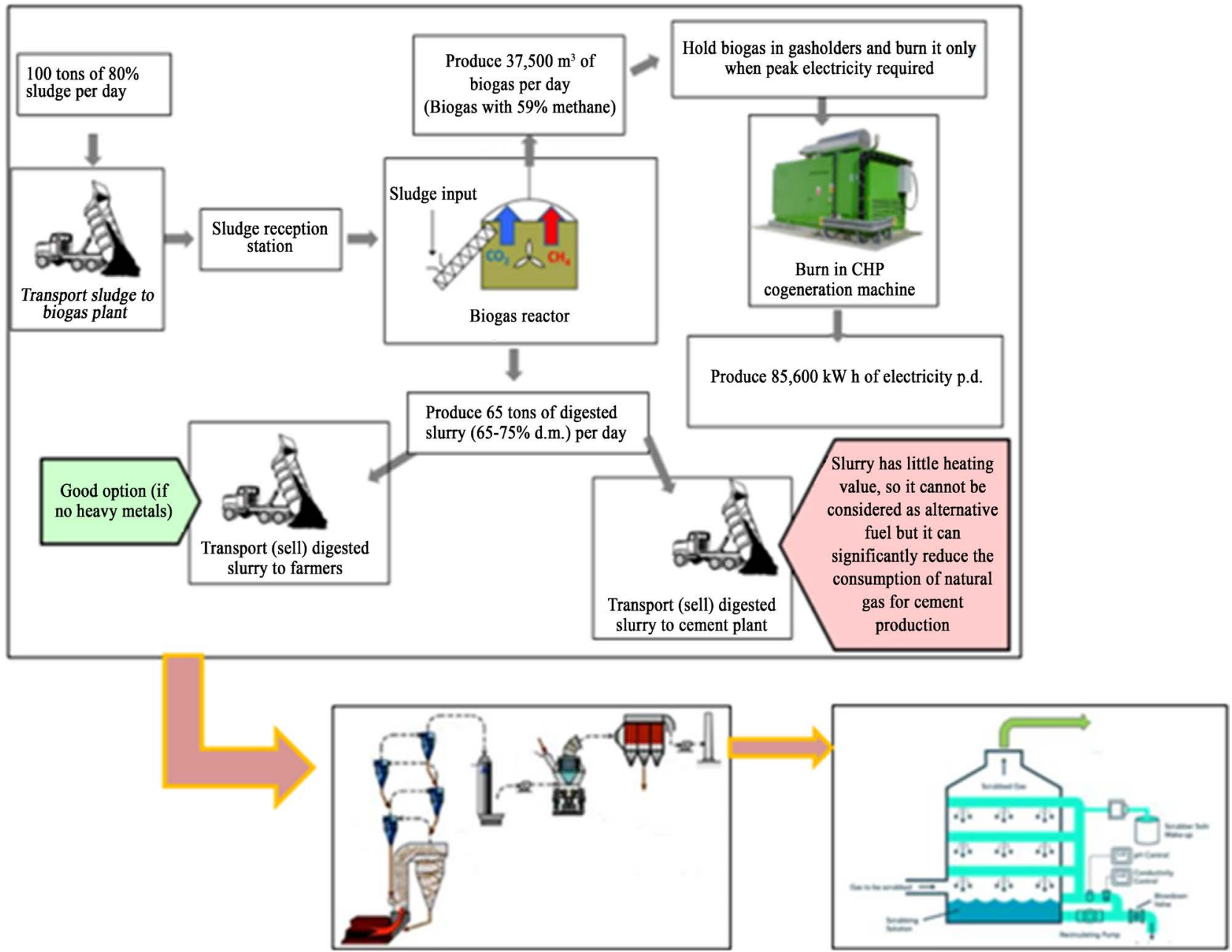

Figure 20. Process flow diagram of the recycling system. 


\section{Conclusion}

In conclusion, biogas production and co-firing in cement kilns are potentially profitable to pursue (see Figure 20). If sewage input is 100 tons per day, it is more profitable to burn sludge in cement kilns. This will offer $100 \%$ recycling of the produced dry waste. Furthermore, this technology is the least expensive and the least cost-demanding. Currently, selling upgraded biogas to the gas-grid at the market price does not produce good revenues. However, the situation may change in the future. Today, biogas production has a potential of application in Oman if the produced gas is burnt in a CHP generator to produce electricity at peak time.

Moreover, it has been found also that digested biogas slurry is potentially a very good fertilizer for farming. However, much is unclear about heavy metals content, market readiness and fertilizing value. It could be recommended that an independent operator which can take care of sludge utilization either via cement kiln co-firing, or by building and running the biogas plant. Future research work is needed to answer the question "can the slurry could be utilized for other manufacturing industries such as steel?"

\section{Acknowledgements}

I would like to acknowledge the support was given to me form Majis industrial Services Company in Suhar port especially Eng. Ahmed ALmazroei (CEO) and Eng. Abdullah Alsadi (CTO) for their highly appreciated support.

\section{Conflicts of Interest}

The authors declare no conflicts of interest regarding the publication of this paper.

\section{References}

GCC Statistical Centre (GCC-STAT), G. S. C. 2019. Data Portal GCC-STAT Website GCC-STAT.

International Energy Agency (IEA), I. E. A. 2019. Data and Statistics. IEA Website IEA.

Abendroth, C., Vilanova, C., Günther, T., Luschnig, O., \& Porcar, M. (2015). Eubacteria and Archaea Communities in Seven Mesophile Anaerobic Digester Plants in Germany. Biotechnology for Biofuels, 8, 87. https://doi.org/10.1186/s13068-015-0271-6

Achternbosch, M., Braeutigam, K.-R., Hartlieb, N., Kupsch, C., Richers, U., \& Stemmermann, P. (2005). Impact of the Use of Waste on Trace Element Concentrations in Cement and Concrete. Waste Management \& Research: The Journal of the International Solid Wastes and Public Cleansing Association, ISWA, 23, 328-337. https://doi.org/10.1177/0734242X05056075

Achternbosch, M., Bräutigam, K., Hartlieb, N., Kupsch, C., Richers, U., Stemmermann, P., \& Gleis, M. (2003). Heavy Metals in Cement and Concrete Resulting from the Co-Incineration of Wastes in Cement Kilns with Regard to the Legitimacy of Waste Utilisation. Karlsruhe: Forschungszentrum Karlsruhe GmbH.

Al Seadi, T., Drosg, B., Fuchs, W., Rutz, D., \& Janssen, R. (2013). Biogas Digestate Quality and Utilization. In A. Wellinger, J. Murphy, \& D. Baxter (Eds.), The Biogas Handbook 
(pp. 267-301). Sawston, CA: Woodhead Publishing. https://doi.org/10.1533/9780857097415.2.267

Al-Musharafi, S., Mahmoud, I., \& Al-Bahry, S. (2013). Heavy Metal Pollution from Treated Sewage Effluent. APCBEE Procedia, 5, 344-348. https://doi.org/10.1016/j.apcbee.2013.05.059

Angelidaki, I., Xie, L., Luo, G., Zhang, Y., Oechsner, H., Lemmer, A., Munoz, R., \& Kougias, P. G. (2019). Chapter 33 Biogas Upgrading: Current and Emerging Technologies. In A. Pandey, C. Larroche, C.-G. Dussap, E. Gnansounou, S. K. Khanal, \& S. Ricke (Eds.), Biofuels: Alternative Feedstocks and Conversion Processes for the Production of Liquid and Gaseous Biofuels (2nd ed., pp. 817-843). Cambridge, MA: Academic Press.

Astals, S., Batstone, D., Mata-Alvarez, J., \& Jensen, P. (2014). Identification of Synergistic Impacts during Anaerobic Co-Digestion of Organic Wastes. Bioresource Technology, 169, 421-427. https://doi.org/10.1016/j.biortech.2014.07.024

Baawain, M. S., Al-Jabri, M., \& Choudri, B. S. (2014). Characterization of Domestic Wastewater Sludge in Oman from Three Different Regions and Recommendations for Alternative Reuse Applications. Iranian Journal of Public Health, 43, 168-177.

Baawain, M. S., Al-Jabri, M., \& Choudri, B. S. (2015). Characterization of Industrial Wastewater Sludge in Oman from Three Different Regions and Recommendations for Alternate Reuse Applications. Iranian Journal of Public Health, 44, 1473-1481.

Baeyens, J., Appels, L., Peng, L., \& Dewil, R. (2016). The Production of Bio-Energy by Microbial (Biogas through Anaerobic Digestion) or Thermal (Pyrolysis) Processes. Renewable Energy, 96, 1055. https://doi.org/10.1016/j.renene.2016.06.012

Barber, D. B. (2012). Sewage Sludge-Inevitable Production of a Renewable Resource. Geelong: AECOM.

Bonten, L. T. C., Zwart, K. B., Rietra, R. P. J. J., Postma, R., De Haas, M., \& Nysingh, S. (2014). Bio-Slurry as Fertilizer: Is Bio-Slurry from Household Digesters a Better Fertilizer than Manure? A Literature Review. Wageningen: Alterra.

Calusinska, M., Goux, X., Fossépré, M., Muller, E. E. L., Wilmes, P., \& Delfosse, P. (2018). A Year of Monitoring 20 Mesophilic Full-Scale Bioreactors Reveals the Existence of Stable But Different Core Microbiomes in Bio-Waste and Wastewater Anaerobic Digestion Systems. Biotechnology for Biofuels, 11, 196-196.

https://doi.org/10.1186/s13068-018-1195-8

Campanaro, S., Treu, L., Kougias, P. G., Luo, G., \& Angelidaki, I. (2018). Metagenomic Binning Reveals the Functional Roles of Core Abundant Microorganisms in Twelve Full-Scale Biogas Plants. Water Research, 140, 123-134.

https://doi.org/10.1016/j.watres.2018.04.043

Casson Moreno, V., Papasidero, S., Scarponi, G. E., Guglielmi, D., \& Cozzani, V. (2016). Analysis of Accidents in Biogas Production and Upgrading. Renewable Energy, 96, 1127-1134. https://doi.org/10.1016/j.renene.2015.10.017

Christodoulou, A., \& Stamatelatou, K. (2016). Overview of Legislation on Sewage Sludge Management in Developed Countries Worldwide. Water Science and Technology: A Journal of the International Association on Water Pollution Research, 73, 453-462. https://doi.org/10.2166/wst.2015.521

Cipurkovic, A., Trumic, I., Hodzic, Z., Selimbasic, V., \& Djozic, A. (2014). Distribution of Heavy Metals in Portland Cement Production Process. Advances in Applied Science Research, 5, 252-259.

Communities, E. (2002). Disposal and Recycling Routes for Sewage Sludge. Luxembourg: European Commission.

De Vrieze, J., \& Verstraete, W. (2016). Perspectives for Microbial Community Composi- 
tion in Anaerobic Digestion: From Abundance and Activity to Connectivity. Environmental Microbiology, 18, 2797-2809. https://doi.org/10.1111/1462-2920.13437

De Vrieze, J., Saunders, A. M., He, Y., Fang, J., Nielsen, P. H., Verstraete, W., \& Boon, N. (2015). Ammonia and Temperature Determine Potential Clustering in the Anaerobic Digestion Microbiome. Water Research, 75, 312-323. https://doi.org/10.1016/j.watres.2015.02.025

Eggerth, L., Diaz, L., Chang, M., \& Iseppi, L. (2007). Marketing of Composts. In Waste Management Series (pp. 325-355). Amsterdam: Elsevier. https://doi.org/10.1016/S1478-7482(07)80015-7

Fontana, A., Patrone, V., Puglisi, E., Morelli, L., Bassi, D., Garuti, M., Rossi, L., \& Cappa, F. (2016). Effects of Geographic Area, Feedstock, Temperature, and Operating Time on Microbial Communities of Six Full-Scale Biogas Plants. Bioresource Technology, 218, 980-990. https://doi.org/10.1016/j.biortech.2016.07.058

Gnansounou, E. (2019). Chapter 4 Economic Assessment of Biofuels. In A. Pandey, C. Larroche, C.-G. Dussap, E. Gnansounou, S. K. Khanal, \& S. Ricke (Eds.), Biofuels: Alternative Feedstocks and Conversion Processes for the Production of Liquid and Gaseous Biofuels (2nd ed, pp. 95-121). Cambridge, MA: Academic Press. https://doi.org/10.1016/B978-0-12-816856-1.00004-X

Gnansounou, E., \& Alves, C. M. (2019). Chapter 8 Integrated Sustainability Assessment of Biofuels. In A. Pandey, C. Larroche, C.-G. Dussap, E. Gnansounou, S. K. Khanal, \& S. Ricke (Eds.), Biofuels: Alternative Feedstocks and Conversion Processes for the Production of Liquid and Gaseous Biofuels (2nd ed.). Cambridge, MA: Academic Press.

Goswami, R., Chattopadhyay, P., Shome, A., Banerjee, S. N., Chakraborty, A. K., Mathew, A. K., \& Chaudhury, S. (2016). An Overview of Physico-Chemical Mechanisms of Biogas Production by Microbial Communities: A Step towards Sustainable Waste Management. 3 Biotech, 6, 72. https://doi.org/10.1007/s13205-016-0395-9

Guo, Q., Majeed, S., Xu, R., Zhang, K., Kakade, A., Khan, A., Hafeez, F. Y., Mao, C., Liu, P., \& Li, X. (2019). Heavy Metals Interact with the Microbial Community and Affect Biogas Production in Anaerobic Digestion: A Review. Journal of Environmental Management, 240, 266-272. https://doi.org/10.1016/j.jenvman.2019.03.104

Hall, J. (1999). Ecological and Economical Balance for Sludge Management Options. Proceedings of the Workshop on Problems around Sludge, Stresa, 18-19 November 1999.

Han, S., Liu, Y., Zhang, S., \& Luo, G. (2016). Reactor Performances and Microbial Communities of Biogas Reactors: Effects of Inoculum Sources. Applied Microbiology and Biotechnology, 100, 987-995. https://doi.org/10.1007/s00253-015-7062-7

Heezen, P. A., Gunnarsdóttir, S., Gooijer, L., \& Mahesh, S. (2013). Hazard Classification of Biogas and Risks of Large Scale Biogas Production. Chemical Engineering Transactions, 31, 37-42.

Heidenreich, S., Müller, M., \& Foscolo, P. U. (2016). Advanced Biomass Gasification: New Concepts for Efficiency Increase and Product Flexibility. Cambridge, MA: Academic Press. https://doi.org/10.1016/B978-0-12-804296-0.00006-3

Heyer, R., Benndorf, D., Kohrs, F., De Vrieze, J., Boon, N., Hoffmann, M., Rapp, E., Schlüter, A., Sczyrba, A., \& Reichl, U. (2016). Proteotyping of Biogas Plant Microbiomes Separates Biogas Plants According to Process Temperature and Reactor Type. Biotechnology for Biofuels, 9, 155. https://doi.org/10.1186/s13068-016-0572-4

Hogg, D. (2002). Costs for Municipal Waste Management in the EU. Eunomia Research $\&$ Consulting. 
Hublin, A., Schneider, D. R., \& Džodan, J. (2014). Utilization of Biogas Produced by Anaerobic Digestion of Agro-Industrial Waste: Energy, Economic and Environmental Effects. Waste Management \& Research, 32, 626-633. https://doi.org/10.1177/0734242X14539789

Jaffar Abdul Khaliq, S., Ahmed, M., Al-Wardy, M., Al-Busaidi, A., \& Choudri, B. S. (2017). Wastewater and Sludge Management and Research in Oman: An Overview. Journal of the Air \& Waste Management Association, 67, 267-278. https://doi.org/10.1080/10962247.2016.1243595

Jimenez, J., Vedrenne, F., Denis, C., Mottet, A., Déléris, S., Steyer, J.-P., \& Rivero, J. A. C. (2013). A Statistical Comparison of Protein and Carbohydrate Characterisation Methodology Applied on Sewage Sludge Samples. Water Research, 47, 1751-1762. https://doi.org/10.1016/j.watres.2012.11.052

Kim, J., Kim, J., \& Lee, C. (2019). Anaerobic Co-Digestion of Food Waste, Human Feces, and Toilet Paper: Methane Potential and Synergistic Effect. Fuel, 248, 189-195.

https://doi.org/10.1016/j.fuel.2019.03.081

Kirkegaard, R. H., Mcilroy, S. J., Kristensen, J. M., Nierychlo, M., Karst, S. M., Dueholm, M. S., Albertsen, M., \& Nielsen, P. H. (2017). Identifying the Abundant and Active Microorganisms Common to Full Scale Anaerobic Digesters. https://doi.org/10.1101/104620

Klocke, M., Mähnert, P., Mundt, K., Souidi, K., \& Linke, B. (2007). Microbial Community Analysis of a Biogas-Producing Completely Stirred Tank Reactor Fed Continuously with Fodder Beet Silage as Mono-Substrate. Systematic and Applied Microbiology, 30, 139-151. https://doi.org/10.1016/j.syapm.2006.03.007

Kollikkathara, N., Feng, H., \& Yu, D. (2010). A System Dynamic Modeling Approach for Evaluating Municipal Solid Waste Generation, Landfill Capacity and Related Cost Management Issues. Waste Management, 30, 2194-2203.

https://doi.org/10.1016/j.wasman.2010.05.012

Kominko, H., Gorazda, K., Wzorek, Z., \& Wojtas, K. (2018). Sustainable Management of Sewage Sludge for the Production of Organo-Mineral Fertilizers. Waste and Biomass Valorization, 9, 1817-1826. https://doi.org/10.1007/s12649-017-9942-9

Kougias, P. G., Treu, L., Benavente, D. P., Boe, K., Campanaro, S., \& Angelidaki, I. (2017). Ex-Situ Biogas Upgrading and Enhancement in Different Reactor Systems. Bioresource Technology, 225, 429-437. https://doi.org/10.1016/j.biortech.2016.11.124

Kovács, K. L., Ács, N., Kovács, E., Wirth, R., Rákhely, G., Strang, O., Herbel, Z., \& Bagi, Z. (2013). Improvement of Biogas Production by Bioaugmentation. BioMed Research International, 2013, Article ID: 482653. https://doi.org/10.1155/2013/482653

Kratzeisen, M., Starcevic, N., Martinov, M., Maurer, C., \& Müller, J. (2010). Applicability of Biogas Digestate as Solid Fuel. Fuel, 89, 2544-2548.

https://doi.org/10.1016/j.fuel.2010.02.008

Li, Y., Wang, H., Zhang, J., Wang, J., \& Lan, O. (2013). Co-Processing Sewage Sludge in Cement Kiln in China. Journal of Water Resource and Protection, 5, 906.

https://doi.org/10.4236/jwarp.2013.59093

Luo, G., Fotidis, I. A., \& Angelidaki, I. (2016). Comparative Analysis of Taxonomic, Functional, and Metabolic Patterns of Microbiomes from 14 Full-Scale Biogas Reactors by Metagenomic Sequencing and Radioisotopic Analysis. Biotechnology for Biofuels, 9, 51. https://doi.org/10.1186/s13068-016-0465-6

Mathew, A. K., Bhui, I., Banerjee, S. N., Goswami, R., Chakraborty, A. K., Shome, A., Balachandran, S., \& Chaudhury, S. (2015). Biogas Production from Locally Available Aquatic Weeds of Santiniketan through Anaerobic Digestion. Clean Technologies and 
Environmental Policy, 17, 1681-1688. https://doi.org/10.1007/s10098-014-0877-6

Moreno, V. C., \& Cozzani, V. (2015). Major Accident Hazard in Bioenergy Production. Journal of Loss Prevention in the Process Industries, 35, 135-144. https://doi.org/10.1016/j.jlp.2015.04.004

Nguyen, D., Nitayavardhana, S., Sawatdeenarunat, C., Surendra, K. C., \& Khanal, S. K. (2019). Chapter 31 Biogas Production by Anaerobic Digestion: Status and Perspectives. In A. Pandey, C. Larroche, C.-G. Dussap, E. Gnansounou, S. K. Khanal, \& S. Ricke (Eds.), Biofuels: Alternative Feedstocks and Conversion Processes for the Production of Liquid and Gaseous Biofuels (2nd ed., pp. 763-778). Cambridge, MA: Academic Press. https://doi.org/10.1016/B978-0-12-816856-1.00031-2

Oman, N. C. F. S. A. I. N. S. O. (2019). Statistical Bulletin. Website NCSI.

Ongen, A., Ozcan, H. K., \& Ozbas, E. E. (2016). Gasification of Biomass and Treatment Sludge in a Fixed Bed Gasifier. International Journal of Hydrogen Energy, 41, 8146-8153. https://doi.org/10.1016/j.ijhydene.2015.11.159

Patterson, T., Esteves, S., Dinsdale, R., \& Guwy, A. (2011). Life Cycle Assessment of Biogas Infrastructure Options on a Regional Scale. Bioresource Technology, 102, 7313-7323. https://doi.org/10.1016/j.biortech.2011.04.063

Poeschl, M., Ward, S., \& Owende, P. (2012a). Environmental Impacts of Biogas Deployment-Part I: Life Cycle Inventory for Evaluation of Production Process Emissions to Air. Journal of Cleaner Production, 24, 168-183. https://doi.org/10.1016/j.jclepro.2011.10.039

Poeschl, M., Ward, S., \& Owende, P. (2012b). Environmental Impacts of Biogas Deployment-Part II: Life Cycle Assessment of Multiple Production and Utilization Pathways. Journal of Cleaner Production, 24, 184-201. https://doi.org/10.1016/j.jclepro.2011.10.030

Prabhu, M. S., \& Mutnuri, S. (2016). Anaerobic Co-Digestion of Sewage Sludge and Food Waste. Waste Management \& Research, 34, 307-315. https://doi.org/10.1177/0734242X16628976

Rachbauer, L., Voitl, G., Bochmann, G., \& Fuchs, W. (2016). Biological Biogas Upgrading Capacity of a Hydrogenotrophic Community in a Trickle-Bed Reactor. Applied Energy, 180, 483-490. https://doi.org/10.1016/j.apenergy.2016.07.109

Rajagopal, R., Massé, D. I., \& Singh, G. (2013). A Critical Review on Inhibition of Anaerobic Digestion Process by Excess Ammonia. Bioresource Technology, 143, 632-641. https://doi.org/10.1016/j.biortech.2013.06.030

Read, S., Marzorati, M., Guimarães, B. C., \& Boon, N. (2011). Microbial Resource Management Revisited: Successful Parameters and New Concepts. Applied Microbiology and Biotechnology, 90, 861. https://doi.org/10.1007/s00253-011-3223-5

Regattieri, A., Bortolini, M., Ferrari, E., Gamberi, M., \& Piana, F. (2018). Biogas Micro-Production from Human Organic Waste-A Research Proposal. Sustainability, 10, 330. https://doi.org/10.3390/su10020330

Rehl, T., \& Müller, J. (2011). Life Cycle Assessment of Biogas Digestate Processing Technologies. Resources, Conservation and Recycling, 56, 92-104. https://doi.org/10.1016/j.resconrec.2011.08.007

Riviére, C., \& Marlair, G. (2010). The Use of Multiple Correspondence Analysis and Hierarchical Clustering to Identify Incident Typologies Pertaining to the Biofuel Industry. Biofuels, Bioproducts and Biorefining: Innovation for a Sustainable Economy, 4, 53-65. https://doi.org/10.1002/bbb.187

Ruan, R., Zhang, Y., Chen, P., Liu, S., Fan, L., Zhou, N., Ding, K., Peng, P., Addy, M., Cheng, Y., Anderson, E., Wang, Y., Liu, Y., Lei, H., \& Li, B. (2019). Chapter 1 Biofuels: 
Introduction. In A. Pandey, C. Larroche, C.-G. Dussap, E. Gnansounou, S. K. Khanal, \& S. Ricke (Eds.), Biofuels: Alternative Feedstocks and Conversion Processes for the Production of Liquid and Gaseous Biofuels (2nd ed.). Cambridge, MA: Academic Press.

Rulkens, W. (2007). Sewage Sludge as a Biomass Resource for the Production of Energy: Overview and Assessment of the Various Options. Energy \& Fuels, 22, 9-15.

https://doi.org/10.1021/ef700267m

Samolada, M., \& Zabaniotou, A. (2014). Comparative Assessment of Municipal Sewage Sludge Incineration, Gasification and Pyrolysis for a Sustainable Sludge-to-Energy Management in Greece. Waste Management, 34, 411-420. https://doi.org/10.1016/j.wasman.2013.11.003

Scarponi, G. E., Guglielmi, D., Moreno, V. C., \& Cozzani, V. (2016). Assessment of Inherently Safer Alternatives in Biogas Production and Upgrading. AIChE Journal, 62, 2713-2727. https://doi.org/10.1002/aic.15224

Scarponi, G., Guglielmi, D., Moreno, V. C., \& Cozzani, V. (2015). Risk Assessment of a Biogas Production and Upgrading Plant. Chemical Engineering Transactions, 43, 1921-1926.

Schnürer, A. (2016). Biogas Production: Microbiology and Technology. In Anaerobes in Biotechnology (pp. 195-234). Berlin: Springer. https://doi.org/10.1007/10_2016_5

Service, H. W. (2019). Formal Communication. RE: Solid Waste Production in Haya STPS Type to ALSAIDI, D. M. S.

Sgroi, F., foderà, M., Trapani, A. M. D., Tudisca, S., \& Testa, R. (2015). Economic Evaluation of Biogas Plant Size Utilizing Giant Reed. Renewable and Sustainable Energy Reviews, 49, 403-409. https://doi.org/10.1016/j.rser.2015.04.142

Sillas-Moreno, M. V., Senés-Guerrero, C., Pacheco, A., \& Montesinos-Castellanos, A. (2019). Methane Potential and Metagenomics of Wastewater Sludge and a Methane-Producing Landfill Solid Sample as Microbial Inocula for Anaerobic Digestion of Food Waste. Journal of Chemical Technology \& Biotechnology, 94, 1123-1133. https://doi.org/10.1002/jctb.5859

Sludge, I. S. W. G. O. S. W. (1997). Sludge Treatment and Disposal: Management Approaches and Experiences. Environmental Issues Series No. 7. https://www.eea.europa.eu/publications/GH-10-97-106-EN-C/file

Su, H., Liu, L., Wang, S., Wang, Q., Jiang, Y., Hou, X., \& Tan, T. (2015). Semi-Continuous Anaerobic Digestion for Biogas Production: Influence of Ammonium Acetate Supplement and Structure of the Microbial Community. Biotechnology for Biofuels, 8, 13. https://doi.org/10.1186/s13068-015-0197-z

Törnwall, E., Pettersson, H., Thorin, E., \& Schwede, S. (2017). Post-Treatment of Biogas Digestate-An Evaluation of Ammonium Recovery, Energy Use and Sanitation. Energy Procedia, 142, 957-963. https://doi.org/10.1016/j.egypro.2017.12.153

Treichel, H., \& Fongaro, G. (2019). Improving Biogas Production: Technological Challenges, Alternative Sources, Future Developments. Berlin: Springer International Publishing. https://doi.org/10.1007/978-3-030-10516-7

Valenti, F., Porto, S. M. C., Dale, B. E., \& Liao, W. (2018). Spatial Analysis of Feedstock Supply and Logistics to Establish Regional Biogas Power Generation: A Case Study in the Region of Sicily. Renewable and Sustainable Energy Reviews, 97, 50-63. https://doi.org/10.1016/j.rser.2018.08.022

Venkiteshwaran, K., Bocher, B., Maki, J., \& Zitomer, D. (2016). Relating Anaerobic Digestion Microbial Community and Process Function. Microbiology Insights, 8, 37-44. https://doi.org/10.4137/MBI.S33593 
Verstraete, W. (2015). The Manufacturing Microbe. Microbial Biotechnology, 8, 36-37. https://doi.org/10.1111/1751-7915.12183

Verstraete, W., Wittebolle, L., Heylen, K., Vanparys, B., De Vos, P., Van de Wiele, T., \& Boon, N. (2007). Microbial Resource Management: The Road to Go for Environmental Biotechnology. Engineering in Life Sciences, 7, 117-126. https://doi.org/10.1002/elsc.200620176

Vigil, S., \& Tchobanoglous, G. (1983). Thermal Gasification of Densified Sewage Sludge and Solid Waste.

Wang, N.-X., Lu, X.-Y., Tsang, Y.-F., Mao, Y., Tsang, C.-W., \& Yueng, V. A. (2019). A Comprehensive Review of Anaerobic Digestion of Organic Solid Wastes in Relation to Microbial Community and Enhancement Process. Journal of the Science of Food and Agriculture, 99, 507-516. https://doi.org/10.1002/jsfa.9315

Wellinger, A., Murphy, J. D., \& Baxter, D. (2013). The Biogas Handbook: Science, Production and Applications. Amsterdam: Elsevier. https://doi.org/10.1533/9780857097415

Werner, J. J., Knights, D., Garcia, M. L., Scalfone, N. B., Smith, S., Yarasheski, K., Cummings, T. A., Beers, A. R., Knight, R., \& Angenent, L. T. (2011). Bacterial Community Structures Are Unique and Resilient in Full-Scale Bioenergy Systems. Proceedings of the National Academy of Sciences, 108, 4158-4163. https://doi.org/10.1073/pnas.1015676108

Yanuka-Golub, K., Baransi-Karkaby, K., Szczupak, A., Reshef, L., Rishpon, J., Shechter, R., Gophna, U., \& Sabbah, I. (2019). An Electrode-Assisted Anaerobic Digestion Process for the Production of High-Quality Biogas. Water Science and Technology, 79, 2145-2155. https://doi.org/10.2166/wst.2019.214

Yusup, S., Bokhari, A., Trinh, H., Shahbaz, M., Patrick, D. O., Cheah, K. W., Azizan, M. T., Ramli, A., Ameen, M., Osman, N., Ahmad Shuhaili, A. F., \& Gurdeep Singh, H. K. (2019). Chapter 2-Emerging Technologies for Biofuels Production. In A. Pandey, C. Larroche, C.-G. Dussap, E. Gnansounou, S. K. Khanal, \& S. Ricke (Eds.), Biofuels: Alternative Feedstocks and Conversion Processes for the Production of Liquid and Gaseous Biofuels (2nd ed., pp. 45-76). Cambridge, MA: Academic Press.

https://doi.org/10.1016/B978-0-12-816856-1.00002-6 